\title{
Bank Governance and Performance: A Survey of the Literature
}

\author{
Catarina Fernandes \\ Polytechnic Institute of Bragança, Portugal \\ Jorge Farinha \\ University of Porto - Faculty of Economics, Portugal \\ Francisco Vitorino Martins \\ University of Porto - Faculty of Economics, Portugal \\ Cesario Mateus* \\ University of Greenwich Business School, London, United Kingdom
}

*Corresponding author; email: c.mateus@greenwich.ac.uk

Keywords: Corporate Governance, Banks, Financial crises, Firm performance.

JEL classification: G01; G21; G34

\section{Journal of Banking Regulation, forthcoming}

This research has been financed by the European Regional Development Fund through COMPETE 2020 - Programa Operacional Competitividade e Internacionalização (POCI) and by Portuguese public funds through FCT (Fundação para a Ciência e a Tecnologia) in the framework of the project POCI-01-0145-FEDER-006890

Este trabalho foi financiado pelo Fundo Europeu de Desenvolvimento Regional (FEDER) através do COMPETE 2020 - Programa Operacional Competitividade e Internacionalização (POCI) e por fundos nacionais através da FCT (Fundação para a Ciência e a Tecnologia), no âmbito do projeto POCI-01-0145-FEDER-006890 


\title{
Bank Governance and Performance: A Survey of the Literature
}

\begin{abstract}
This paper seeks to review the theoretical and empirical literature on the relationship between bank governance and performance, providing a comprehensive understanding of the existing research and offering guidance for investors and regulators on the major points of consensus and disagreement among researchers on this issue.

Although the question of what determines the levels of firms' performance, with special emphasis on the role of the corporate governance, has long been the subject of substantial academic research, it gained increased attention in the banking industry in the last decade due to a series of financial scandals and, more recently, to the global financial crisis. In fact, in the wake of the 2007-2008 financial crisis, bank corporate governance mechanisms received heightened attention, accompanied by the renewed interest in the degree of effectiveness of such mechanisms, and their impact on performance.
\end{abstract}

Given the vast number of influences on corporate performance, such as the numerous characteristics of the board of directors, there is an abundant literature on the determinants of performance. Thus, this paper tries to bring together this diverse body of knowledge into a coherent whole.

Banks have unique attributes that interfere with the way in which the usual corporate governance mechanisms work. Thus, the main differences between banks and non-financial firms, which justify that some of the regularities found in the literature on the relationship between a set of corporate governance mechanisms and performance do not hold for banks, are also analysed.

Then, we extensively review the literature on the board of directors and its impact on performance in the financial crisis and non-financial crisis periods. Finally, we also survey the (very) scarce research on the relationship between board characteristics and bank failures.

Keywords: Banks, Corporate Governance, Performance.

JEL classification: G21; G34. 


\section{Introduction}

Although the need to improve and develop new control mechanisms to minimize the dangers associated with the potential conflicts of interests between corporate stakeholders has long been advocated, large-scale financial scandals and, in particular, the financial crisis have brought into the public domain the issue of the weak corporate governance. This has been the particular and notorious case of the banking sector. The importance of banks in the economy and the nature of their activity, ${ }^{1}$ as well as the significant costs that the failures in bank governance can cause, ${ }^{2}$ make the analysis of the governance mechanisms in the banking sector simultaneously highly specific and important. Moreover, banks also have specific governance issues. ${ }^{3}$ In other words, banks clearly appear to have distinct governance structures than non-financial firms. ${ }^{4}$ "For financial institutions, the scope of corporate governance goes beyond the shareholders (equity governance) to include debtholders, insurance policy holders and other creditors (debt governance). "5(p.219)

Many renowned academics, economists, public authorities and several other observers have argued that poor corporate governance contributed to, or even caused, the collapse of an impressive number of large banks throughout the world. Corporate governance is generally defined as the set of mechanisms for addressing agency problems and controlling risk within the firm and so, it is not surprising that the importance of the effectiveness of corporate practices in the banking sector has been much emphasised. For the Basel Committee on Banking Supervision, ${ }^{6(p 10)}$ "effective corporate governance is critical to the proper functioning of the banking sector and the economy as a whole. Banks perform a crucial role in the economy by intermediating funds from savers and depositors to activities that support enterprise and help drive economic growth. Banks' safety and soundness are key to financial stability, and the manner in which they conduct their business, therefore, is central to economic health. Governance weaknesses at banks that play a significant role in the financial system can result in the transmission of problems across the banking sector and the economy as a whole."

During the financial crisis the quality of governance gained significantly more relevance especially concerning the quality of the board of banks. In fact, boards are one of the most important, arguably even the most important, corporate governance mechanisms that fulfil the following roles: (1) monitor and evaluate management supervisory role, (2) make managerial decisions such as which projects to undertake 
and which employees to hire - managerial role and (3) offer valuable advice advisory role. All these are especially important in certain types of firms ${ }^{\mathrm{i}}$ (e.g., Andres and Vallelado, ${ }^{1}$ Coles et al,${ }^{7}$ Fama and Jensen, ${ }^{8}$ Williamson, ${ }^{9}$ Weisbach, ${ }^{10}$ John and Senbet, ${ }^{11}$ Adams and Mehran, ${ }^{12}$ Raheja, ${ }^{13}$ Adams and Ferreira, ${ }^{14}$ Adams et $a l^{15}$ and Schwartz-Ziv and Weisbach $\left.{ }^{16}\right)$.

The resignations of several top executives (e.g., Charles Prince at Citigroup and Stan O'Neal at Merrill Lynch) and the recommendations by several proxy advisors against the re-election of the board of some banks (e.g., Citigroup) show that the boards are, at least partly, being blamed for their poor performance. The OECD Steering Group on Corporate Governance, for instance, defends that board failures in financial firms are one of the main causes of the financial crisis, evidencing that boards failed to set up appropriate risk strategies and establish suitable metrics to monitor its implementation in a timely and effective manner. ${ }^{17}$ For Francis et al ${ }^{18(\mathrm{p} .40)}$ "although weak corporate boards may not be the direct trigger of the current crisis, corporate board practices could affect the extent to which firms are vulnerable to the financial crisis." To address fundamental deficiencies in bank corporate governance that became apparent during the financial crisis, the Basel Committee on Banking Supervision $^{19}$ has issued a final set of principles for enhancing sound corporate governance practices at banking organisations in a document titled "Principles for Enhancing Corporate Governance" in which the board is identified as a vital part of banks' regulatory reforms. It has undoubtedly never been as vital to understand the governance of banks and their boards as it is now in the aftermath of the financial crisis.

The existing literature on the relationship between corporate boards and performance shows mixed results. One reason commonly cited for the inconclusive results is that a significant number of these studies fail to account for the endogeneity issue that emerges from the joint determination of board structure and the value of the firm. ${ }^{20}$ "Endogeneity leads to biased and inconsistent parameter estimates that make reliable inference virtually impossible." ${ }^{21(\mathrm{p} 6)}$ Thus, the findings of the studies that examine the board structure-performance relationship must be analysed with caution if the empirical methods do not appropriately control for all relevant sources of endogeneity. (22) Moreover, the uniqueness of bank governance suggests that the

\footnotetext{
${ }^{\mathrm{i}}$ Complex firms such as those that operate in multiple segments, are large in size, or have high leverage are likely to have greater advising requirements. ${ }^{7}$
} 
effects of boards on bank performance may be different from their effects on nonfinancial firms and, thus, worthy of special attention. ${ }^{23}$

By surveying the existing literature the main conclusion is that some of the regularities found in the research on the relation between corporate governance and performance of non-financial firms do not hold for banks, as is the case of board independence and board size (e.g., Pathan and Faff, ${ }^{2}$ Adams $^{24}$ and Erkens et $a l^{25}$ ). Thus, recommendations on the corporate governance made to other sectors can be counterproductive in the banking sector. In addition, we can also infer the following:

First, although when dealing with board effectiveness most studies exclude financial firms from their sample, ${ }^{4}$,ii in more recent years, banks and financial institutions have been more closely examined and the question of whether better bank governance (especially concerning boards) leads to improved bank performance has been increased analysed by the literature. ${ }^{\text {iii }}$ This research is very relevant. In fact, better knowledge on how corporate governance of banks impacts on their performance is extremely important as in has policy implications not only at banklevel (e.g., bank management and shareholders) but also at country-level (e.g., regulators, regarding the development and improvement of corporate governance codes and best practices recommendations).

Second, the European context is sparsely analysed by the literature when compared to the United States (US) context, being even more scarce the existence of European cross-country studies.

Third, empirical research analysed the relationship between different corporate governance mechanisms and bank performance using distinct measures of performance:

- Stock returns; $;^{1,2,28-36}$

- Tobin's Q; ${ }^{1,2,4,23,37,38}$

- Return on Equity (ROE); $23,29,31,37,39-43$

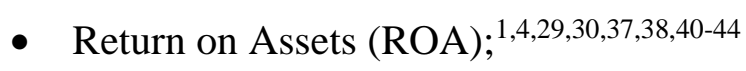

- Accounting earnings; ${ }^{28}$

\footnotetext{
ii For surveys relating to corporate governance in non-financial firms see, for example, Shleifer and Vishny ${ }^{26}$ and Adams et al. ${ }^{15}$

iii Likewise, for de Haan and Vlahu ${ }^{27(\mathrm{p} 2)}$ although "because of the special nature of financial services, most academic papers on corporate governance exclude financial firms from their data and focus on non-financial firms", there is a substantial, but scattered, research on governance of financial institutions, which contrast to the claim by Adams and Mehran. ${ }^{4}$
} 
- Cost efficiency; ${ }^{44}$

- Profit efficiency rank, cost efficiency rank, non-performing loan ratio and costs/assets (total interest plus noninterest expenses divided by assets) ${ }^{39}$

- Bank losses; ${ }^{45}$

- Non-performing assets ratio; ${ }^{30}$

- Financial ratios based on CAMELS ${ }^{\text {iv }}$ indicators; ${ }^{46}$

- Pre-tax operating income, net interest margin, return on average assets and return on average equity; ${ }^{2}$

- Loan losses, rating changes and the composition of the loan portfolio; ${ }^{47}$

- EBIT over total assets; ${ }^{23}$

- Likelihood to participate in a bailout programme; ${ }^{34,48}$

- Amount of bailout funds. ${ }^{34}$

Additionally, Boyd and Runkle ${ }^{49}$ examined the relationship between the size of banking firms and their performance using as indicator of performance ROE, ROA and Tobin's Q. More recently, in the context of the financial crisis, the literature highlighted the role of bank size. Banks have an incentive to grow to a size that, in case of misfortune, ensures that they are saved. ${ }^{50}$ Therefore, they have an interest in growing regardless of the risks involved. "Given the potential costs to the economy from a large bank failure, governments are very reluctant to let large banking institutions fail." 51(p.989) Thus, there are banks that are "too big to fail".

Fourth, the impact of board characteristics on bank performance depends on the trade-off between the advantages and disadvantages of the monitoring and advising roles, the two primary roles performed by the board of directors.

The remainder of the paper proceeds as follows. Section 2 defines corporate governance and its different perspectives and, briefly, discusses why it should matter. Section 3 describes the special features of banks and their implications for corporate governance. Section 4 discusses the literature on the relationship between the characteristics of the board of directors and bank performance. Although this survey focus on banks, occasionally relevant evidence on other financial institutions and nonfinancial firms will be discussed, namely for reasons of comparison. Section 5

\footnotetext{
${ }^{\text {iv }}$ CAMELS is an acronym for capital adequacy, asset quality, management, earnings, liquidity and
} sensitivity to market risk. 
presents a short analysis, due to the scarcity of research to date, of the influence of board characteristics on bank failures. Section 6 provides the major conclusions. 


\section{Corporate governance definition, different perspectives and importance}

The concept of corporate governance is often used in academic literature and public debates concerned with its impact on firms, especially on performance, and with the objective of trying to define ideal governance structures. For Shleifer and Vishny ${ }^{26(p 737)}$ "corporate governance deals with the ways in which suppliers of finance to corporations assure themselves of getting a return on their investment." They focus on shareholders by arguing that, contrary to other stakeholders, the former have a sunk investment in the company. If the firm runs into financial distress, shareholders are likely to lose their investment, whereas other stakeholders can walk away with relative easiness. "Because their investment is sunk, shareholders have fewer protections from expropriation than the other stakeholders do."26(p751) In the same way, Denis and McConnell ${ }^{52(\mathrm{p} 2)}$ define corporate governance "as the set of mechanisms - both institutional and market-based - that induce the self-interested controllers of a company (those that make decisions regarding how the company will be operated) to make decisions that maximize the value of the company to its owners (the supplies of capital)", such as, how corporate owners can motivate/encourage corporate managers to deliver them a competitive rate of return.

The standard definition of corporate governance only refers to the protection of shareholders' interests and does not include the defense of other stakeholders' interests. As the managerial decisions impact not only on investors but also on a set of stakeholders who have a relationship with the firm, such as employees and depositors and regulators (these latter in the case of banks), many have advocated a "stakeholder value" rather than a "shareholder value" approach. According to Tirole ${ }^{53(\mathrm{p} 4)}$ "the traditional shareholder approach is too narrow a view of an economic analysis of corporate governance." For Goergen ${ }^{54}$ putting all the focus on shareholders one neglects that other types of stakeholders (e.g., employees) often make sunk investments in the firms they deal with. For example, employees specialising their human capital in a way that is better adequate to the needs of a specific firm, make such capital less marketable to other firms and thus, less valuable. Accordingly, it seems that stakeholders other than shareholders are not in a different position and should, therefore, be treated in an identical way. John and Senbet ${ }^{11}$ provide a wider definiton of corporate governance, since for them (p.372) “corporate governance deals with mechanisms by which stakeholders of a corporation exercise control over corporate insiders and management such that their interests are protected." They 
include as stakeholders not just shareholders but also employees, creditors and other interested parties. Similarly for OECD ${ }^{55(\mathrm{p} 11)}$ “corporate governance involves a set of relationships between a company's management, its board, its shareholders and other stakeholders", which is one key element that improves a firm's performance and competitiveness. The governance mechanisms can be characterised as internal or external, ${ }^{52}$ being the board of directors one of the main internal mechanisms. Whether the governance mechanisms actually serve the purpose of creating value is an issue of the utmost importance, with value creation being usually measured through a particular set of performance measures.

The governance of banking firms is different from that of unregulated nonfinancial firms. ${ }^{4,12}$ Furthermore, the problems with poor governance are more severe for banks than for non-bank firms and their failures have even more substantial costs. ${ }^{56}$ Due to the specificities of banks and their impact on the stability of the financial system, ${ }^{12,57,58}$ since the onset of the 2007-2008 financial crisis, governments worldwide have launched a massive and unprecedented bailout package to support banks in distress. ${ }^{59,60}$ At country-level, regulators are concerned about the impact of governance on the performance of banks because the health of the overall economy depends upon their performance. ${ }^{12}$ Indeed, "good corporate governance of banks is of a vital concern to banks themselves as well as to the banking supervisors."61(p411) Thus, in addition to shareholders, depositors and other creditors, supervisors and regulators have a direct interest in bank performance. Becht et $a l^{3(\mathrm{p} 445)}$ also note that "not only shareholders but also depositors, other creditors, transaction counterparties, and, in most countries, also the taxpayers, are at risk from banks' activities. It follows that [governance] mechanisms should be in place to protect not just the interests of shareholders (the primary focus of much of the literature on corporate governance (...) but also the interests of these other constituencies." As a result, the board of directors of a bank is assigned a vital role in the bank's governance structure. This role of the board of directors, in order to ensure sound governance, is critical because the fiduciary duties of directors ("duty of care" and "duty of loyalty") expand beyond shareholders. ${ }^{57, v}$ According to Adams and Mehran ${ }^{12}$ and Adams, ${ }^{62}$ boards of financial firms may face more pressure to satisfy non-

\footnotetext{
${ }^{\mathrm{v}}$ Also, Macey and $\mathrm{O}^{\prime} \mathrm{Hara}^{57(\mathrm{p93})}$ argue that "to the extent that fiduciary duties lower agency costs by reducing the freedom of management to act in its own unconstrained self-interest, such duties will be especially valuable devices in the banking context because of the inherent difficulties in monitoring banks."
} 
shareholder stakeholders than boards of non-financial firms. Regulators, for instance, expect boards to act to guarantee the safety and soundness of the banks, a goal that may not necessarily be in shareholders' best interest. ${ }^{24}$

The weak corporate governance in the banking industry is often identified as one of the causes of the global financial crisis ${ }^{63}$ or even its major cause. ${ }^{17}$ The United States Financial Crisis Commission ${ }^{64(\mathrm{pxviii})}$ on its final report concluded that "dramatic failures of corporate governance and risk management at many systemically financial institutions were a key cause of this crisis." In the United Kingdom (UK), David Walker was commissioned to recommend measures to enhance board-level governance at banks to the government. ${ }^{65}$ Such recommendations served as a basis for the 2010 UK Corporate Governance Code. Also, following the crisis, Corporate Governance Codes of several countries worldwide emphasise board characteristics, highlighting, amongst others, that: (1) the board should have a size that enables it to perform its duties in an efficient manner and (2) board members must have relevant experience, knowledge, qualifications, competence and diversity. For example, since January 2008, Norway has enforced a gender quota requirement for corporate board membership at all public limited liability companies. They are obliged, by law, ${ }^{\mathrm{vi}}$ to ensure that at least $40 \%$ of their board of directors are women. Concerning board busyness, in France, Germany and Denmark, for instance, there are limits on the number of directorships that directors can hold. ${ }^{\mathrm{vii}}$ At the sime time, the empirical literature also "defies" some governance principles, as is the case of board independence. Although, even before the crisis, the Corporate Governance Codes of countries worldwide, as well as the Sarbanes-Oxley Act of 2002 (SOX) and the NYSE and Nasdaq exchange listing standards have been promoting board independence, ${ }^{\text {viii }}$ the empirical evidence points to a different direction. In fact, Erkens et $a l^{25}$ find that board independence is associated with worse stock returns of financial firms during the crisis and $\mathrm{Adams}^{24}$ reports that banks receiving Troubled Assets Relief Program (TARP) funds had more independent boards. Also, Pathan and Faff ${ }^{2}$ show that independent directors reduce US bank performance. This suggests that independent directors may lack information and may not have the expertise necessary

\footnotetext{
${ }^{\text {vi Public Limited Liability Companies Act } § 6-11 a . ~}$

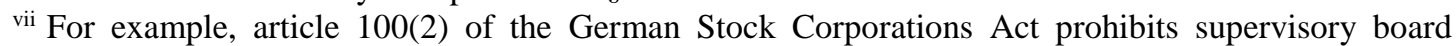
members from serving on more than ten supervisory boards of any incorporated companies that are legally required to have a supervisory board, although up to five additional directorships are allowable for group companies.

viii Additionally, SOX, NYSE, and Nasdaq have tightened the definition of independent director.
} 
to oversee the complex nature of the banking activity. Moreover, Beltratti and Stultz ${ }^{32}$ find that banks with a shareholder-friendly board, which are banks that conventional wisdom would have considered to be better governed, performed worse during the crisis. For them (p.2) "shareholder-friendly boards created more value for shareholders through their decisions before the crisis, but during the crisis these decisions were associated with poor outcomes that could not be forecasted." A possible explanation is that "banks with more shareholder-friendly boards invested more aggressively in highly-rated tranches of subprime securitisations." 


\section{Why are banks special and how their specificities impact on governance?}

Banks are special financial institutions creating distinct corporate governance challenges. ${ }^{37}$ Consistently with this, for instance, Adams and Mehran ${ }^{12}$ and Macey and $\mathrm{O}^{\prime} \mathrm{Hara}^{57}$ emphasise the importance of taking into consideration differences in governance between banking and non-banking. Banks have special characteristics that increase corporate governance problems and might reduce the effectiveness of many traditional governance mechanisms. ${ }^{3,61,66-68}$ Specifically, as Adams and Mehran ${ }^{12}$ and Adams $^{62}$ document, the board of directors of banks differs considerably from those of non-financial firms. Caprio and Levine, ${ }^{66}$ for example, highlight the fact that the role of the board is fundamental because neither the small equity and debt holders nor the market for corporate control (e.g., takeovers) and market competition can enforce an effective governance at banks. Also, for Becht et al ${ }^{3(\mathrm{p} 438)}$ "the very nature of the banking business weakens the traditional corporate governance institutions of board and shareholder oversight. Banks have the ability to take on risk very quickly, in a way that is not immediately visible to directors or outside investors."

There is an abundant literature that examines the particularities of banks that make them unique and justify a separate analysis., ${ }^{3,5,12,27,57,61,62,66-73}$ This can be summarized in the following way:

First, banks are generally more opaque than non-financial firms and their activity is more complex. The quality of bank loans as well as the quality of other bank' assets are not readily observable, which makes it difficult to accurately assess the risks they bear. ${ }^{61,67,70,74}$ Also, the complexity of several financial instruments makes it more difficult to measure and evalute risks. ${ }^{68,70}$ During the financial crisis, for example, the risk associated with many financial innovations, such as securitized products, were not properly understood and managed (e.g., Dell'Ariccia $e t a l^{75}$ and Carlin et $\left.a l^{76}\right)$. Additionally, the competition among rating agencies for corporate customers do not lead to an unbiased assessment of risks as needed by investors. ${ }^{77}$ To worsen this situation, in recent years rating agencies have had to evaluate new and complex financial assets for which there existed no record of historical data and no appropriate models of risk quantification (see, Buiter ${ }^{78}$ ). Moreover, banks can alter the risk composition of their assets more quickly than most non-financial industries $^{67,73}$ and such change might not be immediately noticeable to directors or outside directors. $^{3,73}$ Both the complexity and opacity of the banking business increases the asymmetry of information ${ }^{1,67,68,70,79}$ and diminishes the capacity of 
stakeholders to monitor the decisions of bank managers. ${ }^{1}$ Even knowledgeable outside owners will find monitoring difficult in the presence of these attributes. ${ }^{66}$ Hence, the role of boards as a mechanism for corporate governance of banks takes on particular importance in these circumstances. The management of bank opacity and complexity "requires a board that not only monitors managers efficiently, but also gives managers access to independent and valuable advice to run the bank."1(p2571) Thus, the board becomes a crucial mechanism to monitor and advise managers. In particular, bank directors' specific knowledge of the complexity of the banking activity allows them to monitor and advise managers efficiently. ${ }^{1}$ Additionally, Becht et $a l^{3(\mathrm{p} 438)}$ notice that "a multitude of quickly evolving and technically complex trading activities need to be monitored by specialists who are in short supply."

Second, banks are highly leveraged institutions. ${ }^{3,12,61,80-82}$ This high leverage raises the probability of bank failures ${ }^{61,73}$ and depositors as well as other debtholders will demand a higher risk premium as compensation for the higher risk of insolvency. ${ }^{61}$ Additionally, in the presence of high leverage the conflict of interest between shareholders and debtholders interacts with the equity governance in banks. ${ }^{73}$ Depositors are the primary claimholders ${ }^{80}$ in banks, and their interest might differ significantly. ${ }^{73}$ High leverage of banking firms and regulation may also affect the ability of external governance mechanisms to solve the governance problems of these firms. "For example, the absence of an active market for corporate control in the banking industry prevents better performing firms from taking over the poorly performing ones and removing their boards."12(p126)

Third, banks are heavily regulated and supervised. ${ }^{3,61,66,80}$ Given their role as the key players in both the credit and payment systems ${ }^{1,66}$ and in the economic development and the stability of the overall financial system ${ }^{1,73,79}$ and due to the vulnerability of banks to runs ${ }^{61}$ since, for instance, the effects of individual bank failure might be a contagious run on otherwise healthy banks, ${ }^{66}$ governments tightly regulate and supervise banks. For Furfine $\mathrm{e}^{79(\mathrm{p} 33)}$ "banks have traditionally been both regulated and supervised in order to protect them from failure and to maintain the safety and viability of the financial system." Similarly, for John et al ${ }^{73(\mathrm{p} 313)}$ "bank regulation is justified by the negative externalities that are associated with a bank failure." Thus, well-governed banks are important to the stability of the entire financial system. To achieve its goals, the regulator might impose restrictions on the banking business such as: (1) limit the investments choices of banks and establish 
capital requirements ${ }^{73,80}$ and (2) influence managerial decisions and restrict risk choices. ${ }^{61,73}$ Additionally, the regulator might also impose mandatory standards for the quality and attributes of bank governance (e.g. restrictions on the composition of the board of directors or limitations on equity ownership concentration). Thus, bank regulation can change traditional corporate governance mechanisms (e.g., Andres and Vallelado, ${ }^{1}$ Prowse, ${ }^{69}$ Laeven and Levine,${ }^{83}$ John et $a l^{84}$ and Ellul and Yerramilli $\left.{ }^{85}\right)$. Regulators are one of the main stakeholders, but their goals may collide with those of the other stakeholders. ${ }^{86}$ For Adams and Mehran ${ }^{12}$ there is, in theory, a conflict of interest between the goals of regulators (safety and soundness) and those of shareholders (value maximisation). "When a conflict exists between value maximisation and the need to support prudent operations, regulators expect boards to balance these concerns effectively, by ensuring that bank performance as well as safety and soundness are taken into account." 12(p136) (Moreover, a higher standard of accountability for the board of regulated firms may, eventually, hamper the ability to attract and retain competent directors, which, in turn, could negatively affect bank performance. $^{12}$

Although monitoring by regulators may represent an additional governance mechanism, ${ }^{\text {ix }}$ their presence can also aggravate governance problems. ${ }^{1}$ For instance, regulators might restrict competition and discipline banks by imposing limitations on the concentration of ownership, ${ }^{57,66,69}$ which reduce the role of market forces in the market for corporate control. ${ }^{66}$ Hostile takeovers might discipline managers' behaviour because they increase the threat of managers being removed due to poor performance. ${ }^{\mathrm{x}}$ The threat of potential hostile takeovers induces managers to act in the best interest of shareholders to avoid being fired (in a takeover) ${ }^{89,90}$ However, the imposition, by regulators, of several restrictions on the banking system lowers the frequency of hostile takeovers and makes these insufficient to discipline bank managers, decreasing the efficiency of the market for corporate control. ${ }^{67,69}$ Regulation as well as valuation difficulties also weaken the potential role of the market for corporate control. ${ }^{3}$ In addition, regulators might pursue their own interests as a regulator (e.g., Boot and Thakor ${ }^{91}$ ).

\footnotetext{
${ }^{\text {ix }}$ Regulation might also be an additional external governance force that acts at the macroeconomic level - in the banking sector as a whole - and at the microeconomic level - in the individual banks sphere ${ }^{87}$ For example, as part of their efforts to monitor banks, regulators supervise the functioning of bank boards. ${ }^{1}$

${ }^{x}$ See, e.g., Scharfstein ${ }^{88}$ who analyses the disciplinary role of takeovers in the context of asymmetric information between shareholders and managers.
} 
Fourth, the specific nature of banking makes it susceptible to greater moral hazard problems, as is the case of deposit insurance..$^{3,61,70}$ Deposit insurance, while aimed compensating the existence of deficiencies in the monitoring and control of banks, exacerbate the particular problems that are inherent in banks' corporate governance. ${ }^{61}$ When protected, the depositor has little incentive to monitor the bank's activities $^{1}$ and to withdraw funds if the bank is taking on too much risk. Thus, despite the positive effect of deposit insurance on preventing depositor runs, ${ }^{x i}$ this can encourage excessive risk-taking ${ }^{57}$ and incentive bank shareholders to take on inefficient risk. ${ }^{69}$ The problem of moral hazard is worse in situations where a bank is at or near insolvency. "In such a situation, the shareholders have a strong incentive to increase risk because they can allocate their losses to third parties while still receiving any gains that might result from the risky behavior." ${ }^{57(\mathrm{p} 97)}$ Excessive bank size can also exacerbate important moral hazard problems (the issue known as "toobig-to-fail").

In short, on the one hand, banks have specific governance issues, distinct from those of non-financial firms, whereas on the other hand, the board of a bank plays a critical role in achieving effective governance. ${ }^{2}$ In the distinct context that involves the bank's activities, the board is a key element in its governance structure. ${ }^{1,12,57,61,66}$

\footnotetext{
${ }^{\mathrm{xi}}$ Deposit insurance is a means to discourage withdrawals of deposits and short-term funding from banks that would otherwise be solvent. ${ }^{3}$
} 


\section{Characteristics of the board of directors and bank performance}

The relevance of the role of the board of directors has been highlighted by abundant literature, media and public debates. Mizruchi ${ }^{92\left(\mathrm{p}^{433)}\right.}$ characterises the board as the "ultimate centre of control", Baysinger and Butler ${ }^{93}$ notice that "the board of directors, which has the power to hire, fire, and compensate senior management teams, serves to resolve conflicts of interest among decision makers and residual risk bearers" and John and Senbet ${ }^{11(\mathrm{p} 379)}$ note that "the board of directors is central to corporate governance mechanisms in market economies." Similarly, for Helland and Sykuta94(p167) "the basic unit of analysis in corporate governance is the board of directors" and for Andres and Vallelado ${ }^{1}$ the board of directors is one of the main governance mechanisms. Pathan and Faff ${ }^{2(1573)}$ also refers that "a bank's board plays a vital role in achieving effective governance." Moreover, "the ability of a board to recommend appropriate actions and to monitor the implementation of these recommendations is likely to determine the financial position of the firm and the outcome of a bankruptcy proceeding." ${ }^{95(\mathrm{p} 271)}$ Academic research generally recognises the following two main roles for boards: a supervisory/monitoring role (e.g., Fama and Jensen, ${ }^{8}$ John and Senbet, ${ }^{11}$ Raheja, ${ }^{13}$ Adams and Ferreira, ${ }^{14}$ Hermalin and Weisbach ${ }^{96}$ and Almazan and Suarez ${ }^{97}$ ) where the aim is to monitor and evaluate management and an advisory role (e.g., Coles et al, ${ }^{7}$ Adams and Ferreira, ${ }^{14}$ Helland and Sykuta ${ }^{94}$ and Coles et $a l^{98}$ ) the purpose of which is to offer valuable advice, namely for key strategic decisions. By bringing expertise and knowledge, the board plays an important role in formulating and implementing business strategy. On the other hand, the board can oblige management to justify its proposed actions and to invoke reasoned arguments to support the options it has chosen, thus, performing a monitoring function. In this context, "directors monitor, advise, punish, and reward"94(p167) and accordingly "the board exists primarily to hire, fire, monitor, and compensate management, all with an eye toward maximizing shareholder value." $52(\mathrm{p} 2)$ In fact, "the common apex of the decision control systems of organisations (...) is a board of directors (...) that ratifies and monitors important decisions and chooses, dismisses, and rewards important decision agents. "8(p323) Specifically, bank boards play a relevant role in bank governance, either monitoring managers or advising them in the design and implementation of strategies. ${ }^{1}$

Governance literature defends that boards fulfill their functions of advising and monitoring management by choosing board characteristics (e.g. composition and size) 
adequately. ${ }^{13,14,99}$ In other words, certain features of boards reflect the motivation and ability of directors to effectively perform their supervisory and advisory duties. ${ }^{1}$ For example, "the effect of board size on bank value is a trade-off between advantages (monitoring and advising) and disadvantages (coordination, control and decisionmaking problems)."1(p2571) Also, "the trade-off perspective on board capabilities argues that firms attempt to balance monitoring and advising functions primarily by adjusting the proportion of inside versus outside directors." 100 This reseach suggests that outside directors contribute mainly to the monitoring role because they are independent of management. On the other hand, inside directors contribute primarily to the advising function because they have more firm-specific knowledge, critical to mitigating problems arising from information asymmetry between the board and management. Thus, the effect of board characteristics on performance depends on which of the two main roles is more relevant for firms, regarding a specific attribute of the board, or, to put it in another way, on the needs of firms for advising vis-à-vis monitoring (and vice-versa).

The board of directors is thus at the centre of the public discussion regarding corporate governance reform, in particular concerning how board characteristics contribute to performance. Next, we review the literature on the relationship between a large number of board attributes and bank performance.

\subsection{Board independence and performance}

Board independence and board size are the two board characteristics that have been more extensively studied in the US ${ }^{52}$ in both academic and practitioner work, trying to analyse whether and to what extent such characteristics affect performance. On the one hand, independent directors, i.e. directors that have no social or business relationships with management, ${ }^{\text {xii }}$ are better monitors of management precisely because they do not have any connection with management (e.g., Hermalin and Weisback ${ }^{20}$ ). Also, they are considered more effective supervisors of management because they have concerns about their personal reputation, ${ }^{\text {xii }}$ that affects their ability to receive additional director appointments. ${ }^{8}$ On the other hand, "the CEO may

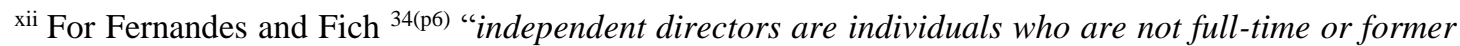
employees of the bank, relatives of a bank employee, or current or previous consultants of the financial institution."

xiii Gilson ${ }^{101}$ supports the importance of director reputation by finding evidence that directors who resign from financially distressed firms subsequently serve on fewer boards of other companies
} 
choose outside directors who will give good advice and counsel, who can bring valuable experience and expertise to the board, and who offer a contrast to the perspectives and opinions found within the firm." 102(1590) "In addition, they bring a different perspective to bear on problems management faces and thus serve as a valuable advisory role." ${ }^{4(\mathrm{p} 248)}$ This role is particularly relevant in complex firms which have greater advising requirements, ${ }^{7}$ such as banks. Firms for which firmspecific knowledge of insiders is relatively important are likely to benefit from greater representation of them on the board. ${ }^{7}$ Theoretically, it has long been recognised that the effectiveness of independent directors is limited by their inferior information compared to corporate insiders. ${ }^{\text {xiv }}$ Thus, in a context of high information asymmetry the inclusion of more inside directors may be beneficial, as they have greater specific information about the firm's activities. ${ }^{8}$ Moreover, the problems associated with independent directors' lack of firm-specific knowledge may also be exacerbated for banks because regulatory restrictions may act to limit the pool of directors from which they can choose $\mathrm{e}^{4,12, \mathrm{xv}}$ and because the complex nature of their businesses. ${ }^{1,3,24,73}$ The problem of the limitations of the set of directors that banks have at their disposal "is likely to get worse the more subsidiaries the BHC [bank holding company] has, as each subsidiary must have sufficient directors for its board. If so, these bank-level regulations may make it more difficult to detect beneficial effects of large and independent boards in BHCs." ${ }^{4(\mathrm{p} 247)}$ Additionally, the advising requirements are relevant for firms operating in more uncertain environments, namely those that have a greater need for specialised knowledge, ${ }^{2}$ as is the case of banks. In fact, "independent directors are less likely to have an in-depth knowledge of the internal workings of the banks on whose boards they sit" and "they are also less likely to have the financial expertise to understand the complexity of the securitisation processes banks were engaging in or to assess the associated risks banks were taking on."24(p32) In comparing board independence between banks and non-financial firms, both in the

\footnotetext{
xiv A potential disadvantage of outside directors is that they may lack relevant firm-specific information. ${ }^{14}$

${ }^{\mathrm{xv}}$ A higher standard of responsibility, requirement and obligations for the board of banks as well a set of regulation restrictions, imposed by regulators to ensure the health of the financial system, may, eventually, to make it difficult to attract and retain talented directors. ${ }^{12}$ Also, according to Adams and Mehran"12(136) "a higher standard of accountability for bank directors and, arguably, well-defined regulatory expectations have led the government to sue directors to recover some of the losses in bank failures, particularly during periods of poor economic performance and large numbers of failures." The Government has stepped up its efforts to recover some losses by suing bank directors and, as a result, banks are finding it more difficult to keep and recruit board members, because directors fear the high risk of sitting on a bank's board. ${ }^{103}$
} 
US and in Europe, empirical literature shows that the percentage of independent directors is higher on bank boards than on non-financial firms boards (see John et $a l^{73}$ ). However, the existing literature on the relationship between board independence and bank performance shows mixed results: a positive relationship, ${ }^{38,43}$ a negative relationship, ${ }^{2,46}$ an inverted U-shaped relationship ${ }^{1}$ and an insignificant relationship. ${ }^{4,34,37}$ Other research shows that such relationship depends on the environmental conditions and so, it is sensitive to the economic context. Minton et $a l^{35}$ find that board independence is negatively associated with bank performance, during the crisis period, but not statistically significant during the 2003-2006 precrisis period.

Liang et $a l^{43}$ find, for a sample of Chinese banks during the period of 20032010, that the proportion of independent directors has significantly positive impacts on both bank performance and asset quality. Similarly, in a cross-country study, although it is not the main focus of their paper, García-Meca et $a l^{38}$ show that the percentage of independent directors on the board of directors positively impacts on performance, measured by Tobin's Q and, alternatively, by ROA. Also, for a sample of 212 US bank holding companies, from 1997 to 2004, Pathan and Skully 104 document that banks benefit from more independent directors when the costs of monitoring managers are low. On the contrary, Wang et $a l^{46}$ using a sample of BHCs in the US show that the percentage of non-executive directors negatively impacts on BHCs' performance, suggesting that they have less understanding of the BHCs' activity. Similarly, Pathan and Faff, ${ }^{2}$ based on a sample of 212 large US BHCs over the period 1997-2011, using the Generalised Method of Moments (GMM) estimation technique, find evidence that banks in which boards have more independent directors perform worse. This finding holds during the crisis period. Also, they present evidence that the impact of board structure (board independence, board size and gender diversity) is prevalent particularly for banks with low market power, exposed to external takeovers and/or of smaller size. The negative impact of board independence on performance is confirmed during the financial crisis for financial firms. Erkens et $a l,{ }^{25}$ using a dataset of 296 financial firms from 30 countries, find that firms with more independent directors experienced worse stock returns during the crisis period. ${ }^{\mathrm{xvi}}$ Accordingly, Adams $^{24}$ shows that banks receiving bailout money, in

\footnotetext{
${ }^{x v i}$ The explanation for this result is that independent board members may incentive managers to raise
} 
particular TARP funds, had boards that were more independent than in other banks. Similarly, Minton et $a l^{35}$ find that a more independent board is associated with increases in the likelihood of receiving TARP funds. This suggests that board independence may not necessarily be beneficial for banks because independent directors may not have sufficient expertise to monitor complex banking firms and oversee the actions of the Chief Executive Officer (CEO). ${ }^{24}$ In the crisis period, Aebi et $a l,{ }^{31}$ find a negative relation between board independence and US bank performance, although it is not always significant. Other empirical research shows a non-linear relationship between board independence and bank performance. Andres and Vallelado, ${ }^{1}$ using a sample of large international commercial banks, find an inverted U-shaped relation between the proportion of non-executive directors and performance. They show that the addition of outsiders improves value, but when a critical proportion over the total number of board members is reached, performance starts to diminish. Moreover, the existing literature also reports an insignificant relationship between independent directors and performance. Staikouras et al, ${ }^{37}$ for a sample of European banks for the period 2002-2004, find that the proportion of nonexecutives in the board of directors is positive but statistically insignificant under all measures of performance. Also, Adams and Mehran, ${ }^{4}$ considering a sample of 35 publicly traded BHCs, find that board independence has no significant relation with BHCs' performance. In the context of the financial crisis, Fernandes and Fich, ${ }^{34}$ for a sample of 479 US banks, show that the percentage of directors classified as independent is not statistically related to performance.

\subsection{Board size and performance}

An extensive literature analyses board size in banks comparing it with board size in non-financial firms and examining whether and how it matters for bank performance. Several studies report that banks have larger boards than non-financial firms. ${ }^{12,24,65,105,106}$ For example, Adams and Mehran ${ }^{12}$ find, in a sample of data on 35 BHCs in the US from 1986 to 1999, that BHCs have larger boards, more independent directors and lower performance-based pay for CEOs than non-financial firms. Also, according to the Walker Review, ${ }^{65}$ the board of listed UK banks in 2007/2008 were larger than those of other listed companies, suggesting that bank board size should be 
reduced because "the overall effectiveness of the board, outside a quite narrow range, tends to vary inversely with its size." ${ }^{" 65(\mathrm{p} 41)}$ However for Adams and Mehran ${ }^{12(\mathrm{p} 127)}$ "BHC boards may be larger because of their complex organisational structure."

The second question that has been widely examined by the literature is the impact of board size on performance. In the research of non-financial firms the most common finding is the negative relationship between board size and the performance of the firm ${ }^{20}$ due to the lack of cohesiveness of larger boards as well as their higher coordination and communication costs. ${ }^{13,90,107}$ These costs highlight the difficulty in decision-making as board size increases. So, smaller boards should be more effective because decision-making costs are lower in smaller groups. ${ }^{24}$ When boards are larger it becomes harder for directors to express their opinions and points of view within the restricted time available during the board meetings. ${ }^{107} \mathrm{~A}$ larger board size may also create a free-riding problem, making it more difficult for board members to have a motivation to monitor. ${ }^{13}$ On large boards, since the incentive of an individual director to acquire and understand information as well as to supervise managers is low, it is easier for the CEO to control. ${ }^{90, x v i i}$ However, Coles $e t a l^{7}$ defend that this relationship depends on the firm's complexity. Complex firms (diversified, large or highly levered) are more likely to benefit from a larger board of directors. Moreover, Raheja ${ }^{13}$ argues that since optimal board size is a function of the directors' and the firm's characteristics, a large board may be optimal under certain circumstances.

For banks, the results on the relation between board size and bank performance are again mixed. In fact, the research reports a positive relationship, ${ }^{4,31,38}$ a negative relationship, ${ }^{2,37,43,46}$ an inverted $U$-shaped relationship ${ }^{1,30}$ and no relationship ${ }^{35}$ between board size and performance.

For large US BHCs, from 1965 to 1999, Adams and Mehran ${ }^{4}$ find that board size is positively related to performance. This is consistent with the finding of Coles et $\mathrm{al}^{7}$ that performance increases in board size for complex firms. Using a sample of 159 banks in nine countries, García-Meca $e a^{38}$ also show that board size has a positive impact on performance. Moreover, during the crisis period Aebi $e t a l^{31}$ find that board size is positively associated with bank performance. However, Minton et $a l^{35}$ report that the board size is not significantly related to bank performance both

\footnotetext{
xvii Since agency problems (such as directors' free-riding) become more severe as a board becomes larger, and thus it is easier for the CEO to influence and control the board, CEO power in decisionmaking increases with board size (e.g., Jensen ${ }^{90}$ ).
} 
during the 2007-2008 financial crisis period and the 2003-2006 pre-crisis period. On the other hand, Staikouras $e t a l^{37}$ observe a significant negative relationship between board size and all performance measures used for European banks. This result also holds for US and Chinese samples of banks. Wang et $a l^{46}$ and Pathan and Faff ${ }^{2}$ find that there is a negative impact of board size on US BHC's performance. Also, Liang et $a l^{43}$ show that board size negatively impacts on Chinese banks' performance. They also note that this effect is not only statistically significant but also economically large. Additionally, larger boards are associated with increases in the likelihood of receiving TARP funds. ${ }^{24,35}$ Furthermore, Andres and Vallelado ${ }^{1}$ and Grove et $a l^{30}$ find an inverted U-shaped relation between board size and commercial banks performance. Andres and Vallelado ${ }^{1(\mathrm{p} 2571)}$ note that although "adding new directors is positively linked to a bank's performance, and indicates better manager monitoring and advising, the non-monotonic relation shows that when the number of directors reaches 19, Tobin's $Q$ starts to diminish." Also, Grove et al $l^{30}$ show that board size exhibits a concave relationship with financial performance (measured by ROA of 2008 and the average of the 2006-2008 period). Additionally, their findings reveal that board size has a negative and linear association with financial performance (measured by excess stock return of 2007) and loan quality (measured by the nonperforming assets ratio of 2007, 2008, and the average of the 2006-2008 period).

\subsection{CEO duality and performance}

It has long been argued that when the CEO is also the Chairman ${ }^{\text {xviii }}$ the motivation of the board to monitor and oversee management is compromised due to a lack of independence and conflicts of interests, ${ }^{90}$ reducing the board's ability to ensure that management pursues the development of activities that create value. Supporters of the separation between the roles of CEO and Chairman argue that when the CEO is also the Chairman the agency cost are higher as the ability to supervise the CEO is reduced - the Entrenchment Theory. ${ }^{8,90,107, \text { xix }}$ This reduction in board oversight facilitates the pursuance of the CEO's agenda, ${ }^{109}$ which may diverge from shareholders' goals and, so, negatively affect the performance of the firm. On the

\footnotetext{
xviii The literature refers to the combination of the roles of CEO and Chairman of the board as CEO duality. So, CEO duality exists when a firm's CEO also serves as Chairman of the board of directors.

${ }^{x i x}$ Berger et al ${ }^{108(\mathrm{p} 1411)}$ define entrenchment "as the extent to which managers fail to experience discipline from the full range of corporate governance and control mechanisms, including monitoring by the board, the threat of dismissal or takeover, and stock- or compensation-based performance incentives."
} 
other hand, advocates of the combination of the two roles defend that the choice of board leadership is based on the firm's economic and business environments so, joining both functions in the same individual may be best suited to a firm's conditions - the Efficiency Theory. ${ }^{110,111}$ In this sense, the features of an effective board will change as a function of environmental conditions. ${ }^{x \times / x x i}$ Accordingly, each firm weighs the costs and benefits related to both leadership structures and chooses the one that is best suited to its economic and business conditions. In this context, duality may offer a clear direction of a single leader and, consequently, a faster response to external events, facilitating effective action by the CEO and, thus, leading to higher performance. Additionally, Brickley et $a l^{110}$ refer that some costs related to the separation of the roles have been overlooked by their advocates. These costs incorporate: agency costs of controlling the behaviour of the Chairman, information costs and costs associated with inconsistent decision making of shared authority.

$\mathrm{Pi}$ and Timme ${ }^{44}$ in their research on 112 US banks find that cost efficiency and ROA are lower for banks with CEO duality. Similarly, using a sample of 236 US public commercial banks, Grove et $a l^{30}$ show that CEO duality is negatively associated with financial performance in the pre-crisis period (measured by ROA of 2006 and 2007 and excess stock returns of 2006 and 2007) but not in the crisis period (2008). "This finding is consistent with the suggestion by the financial press that an over-powerful CEO was a key factor leading banks into risky strategies that which in turn, led to poor firm performance and, as a result, several major banks separated the role. "30(p432) Also, Wang et al ${ }^{46}$ report a negative impact on BHCs performance from CEO duality. On the contrary, Aebi et al, ${ }^{31}$ do not find that CEO duality affects performance in their sample of US banks. Additionally, Pathan ${ }^{56}$ shows that CEO power (CEO's ability to control board decision, including CEO duality) negatively affects bank risk-taking because bank managers including CEOs may prefer lower risk due to their non-diversifiable wealth, including human capital invested in their banks, and comparatively fixed compensation (e.g., salary).

\footnotetext{
${ }^{x x}$ This idea is supported by studies linking board composition with environmental conditions as is the case of Pfeffer ${ }^{112}$ and Boyd ${ }^{113}$.

xxi According to Brickley et $a l^{110}$ both leadership structures have costs and benefits and it is not theoretically obvious which of them is the best. In fact, the "optimal structure is likely to vary according to the economic circumstances facing the firm." 110(p218)
} 


\subsection{Board experience and performance}

The effectiveness of internal control mechanisms in any financial or nonfinancial institution relies, in great part, on the monitoring and advising abilities of its board of directors. There is a recent and increasing consensus that the strict and effective performance of both the monitoring and advisory roles depends on the experience of directors, ${ }^{34,45,114}$ particularly from the point of view of risk management. ${ }^{85, x i i} \mathrm{~A}$ more financially knowledgeable board can identify risks that will not pay off or that are unsound for the financial stability and can advise senior managers to avoid such risks. ${ }^{35}$ Alternatively, financial experts can recognise risks that are more beneficial to shareholders in normal times and incentive management to take on those risks. ${ }^{35}$ For Hau and Thum ${ }^{45(\mathrm{p} 719)}$ "effective monitoring of bank managers may involve industry-specific knowledge which depends on experience."

Following the wave of the accounting scandals in the US and in particular in the aftermath of the financial crisis, regulators and shareholder activists, among others, have stressed the need for more financial and banking experience among directors. ${ }^{\text {xxiii }}$ The implicit assumption is that this would lead to better board oversight and advice and hence, would better serve the interests of shareholders. However, it is often asserted that bank board members lack banking and financial experience. ${ }^{17}$ This finding is consistent with Guerrera and Larsen ${ }^{115}$ who report that more than two-thirds of the directors at eight large US financial institutions did not have any significant recent experience in the banking business and more than half had no financial services industry experience at all. ${ }^{\text {xiv }}$ Further, Fernandes and Fich $^{34}$ refer that an analysis of Lehman Brothers and Merrill Lynch prior to their collapse shows that their boards of directors lacked sufficient financial expertise. In Europe, it seems that banking experience is also often quite limited among board members. In the UK, for example, Northern Rock, the first bank in 150 years to suffer a bank run and which ended up being nationalised in 2008 , had just two board members with banking experience. ${ }^{17}$

\footnotetext{
${ }^{x x i i}$ Ellul and Yerramilli ${ }^{85}$, for a sample of 72 BHCs over the 1994 to 2009 period, conclude that board experience and their risk management index (RMI) seem to be substitutes as they find that BHCs that have a larger fraction of independent directors with prior financial industry experience have lower RMI.

xxiii In the survey "2012, Board practices report: Providing insight into the shape of things to come", elaborated in 2012 by Deloitte and Society of Corporate Secretaries \& Governance Professionals, 47\% of directors indicate industry experience as the most desired skill for board success in the next two years.

xxiv Guerrera and Larsen ${ }^{115}$ also discuss the fact that SOX made it more difficult for financial companies to hire financial experts as directors because of the problem of conflicts of interests.
} 
Based on this discussion, some recent literature has been investigating the impact of directors' financial expertise on the performance of European and US banks during the recent financial crisis. ${ }^{34,45} \mathrm{Hau}$ and Thum, ${ }^{45}$ examining the biographical background of 592 supervisory board members in the 29 largest German banks, conclude that the presence of board members with financial experience was negatively related to bank losses in the period 2007-2008. Also, their results reveal that management and financial experience of the board members are systematically higher in privately-owned banks compared to state-owned banks. This "competence gap can largely be attributed to an appointment practice for state-owned banks which stacks the board with politicians and government employees as the shareholder representatives." ${ }^{45(\mathrm{p} 726)}$ In fact, "most of the politically-connected board members made their career in politics and in administration but have little experience in banking and financial markets. "45(p726) Furthermore, in the European context, Cunat and Garicano ${ }^{47}$ show that Spanish cajas whose chairman had no previous banking experience (or no postgraduate education) had significantly worse performance. Experienced, and more educated, chairmen performed better both before the crisis (in 2007) and during the crisis. However, the non-profit nature of the cajas and their close link with political institutions make this result difficult to generalise to international banks. ${ }^{116}$ Also, the lack of financial experience of bank board members in Germany, much more notorious in public banks, is correlated with the existence of political appointments.

For US banks, Fernandes and Fich $^{34}$ show that banks with more financially experienced board members did better during the crisis, exhibiting better stock return performance. In addition, the probability of a bailout as well as the amount of bailout funds as a fraction of bank assets decline as the financial experience of outside directors increases. Thus, banks with financial experts on their boards are less likely to be bailed out and within the banks that receive assistance those with more financial experts receive proportionally less assistance. Aebi et $a l^{31}$ also investigate whether financial experience influenced US bank performance during the crisis. However, in contrast to Fernandes and Fich, ${ }^{34}$ they report that the percentage of directors with experience (present or past) as an executive officer in a bank or insurance company is negatively related to performance in all specifications and significant in two of them. This negative relationship is consistent with the results of Minton et al. ${ }^{35}$ For a sample of US banks, they find that while financial expertise is weakly related to better 
performance before the crisis, it is strongly associated with lower performance during the crisis. Overall, the results are consistent with independent directors with financial expertise supporting increased risk taking prior to the crisis. ${ }^{x x v}$ Srivastav and Hagendorff" $\mathrm{f}^{8(\mathrm{p} 6)}$ state that "board competence in terms of the educational qualifications and prior relevant experience can also have an important bearing on bank risk-taking incentives." Furthermore, Nguyen et $a l^{36}$ analyse how the characteristics of executive directors affect the market performance of US banks, from January 1999 to December 2011. They show that prior work experience, education $^{\mathrm{xxvi}}$ and age create shareholder wealth while gender, non-banking experience or an MBA degree do not lead to any measurable value creation. These wealth effects are moderated by the level of influence of incoming executives. Their magnitude is reduced as bank boards become more independent and is higher if the incoming executive is also appointed as CEO.

One possible explanation for the mixed findings as previously discussed in this sub-section is the use of different proxies for financial expertise. ${ }^{27,73}$

\subsection{Board education and performance}

In addition to directors' banking experience, the qualifications of directors may influence bank performance, as a higher educational level leads to better judgments on a particular investment strategy and thus, to better corporate decisions. This is particularly important in the case of banking firms because the complexity of their activity often requires a great amount of specific knowledge. OECD Corporate Governance Principles, more specifically "the annotation to Principle VI.E.3 (board members should be able to commit themselves effectively to their responsibilities) touches on board training and refers that "this might include that board members acquire appropriate skills upon appointment (...)",'17(p23) Widespread belief that director qualifications and experience matter is also reflected in the amendments to

\footnotetext{
$\mathrm{xxv}$ "In stable times, the presence of financial experts among independent directors is associated with higher risk taking and slightly above-average performance. Since financial expertise on the board is related to more risk taking, it is not surprising that banks with more independent financial experts underperform when the crisis hits. "35(p354)

xxvi Specifically, education is proxied by an Ivy League Education. Nguyen $e t a l^{36}$ choose Ivy League institutions as an indicator of highly reputable universities. According to them (p.115) "while not a perfect proxy for academic excellence, there is empirical evidence showing that Ivy League graduates perform better than non-Ivy League ones." Ivy League institutions are eight northeastern American higher education institutions, including Brown University, Columbia University, Cornell University, Dartmouth College, Harvard University, Princeton University, University of Pennsylvania and Yale University.
} 
the US Securities and Exchange Commission's disclosure rules introduced in December 2009. ${ }^{117}$

Such amendments are intended to improve disclosures regarding risk, corporate governance, the qualifications of the directors and compensation.

However, academic papers emphasise experience rather than qualifications. Exceptions are the studies by Nguyen et al, ${ }^{36} \mathrm{Hau}$ and $\mathrm{Thum}^{45}$ and Cunat and Garicano. ${ }^{47}$ Hau and Thum ${ }^{45}$ analyse the impact of the educational background of supervisory board members on the performance of banks during the financial crisis, defining three levels of educational achievement (Business/Economics degree, MBA degree and $\mathrm{PhD}$ degree in Business/Economics). The results reveal that board's average educational achievement does not show a statistically significant correlation with bank losses. In the same way, Nguyen et $a l^{36}$ find that appointing executives with an MBA degree is not linked to measurable value effects. In contrast, Cuñat and Garicano ${ }^{47}$ find that cajas whose chairman did not have postgraduate education have significantly worse performance. Additionally, Berger et $a l^{118}$ investigate how a set of characteristics of executives, such as educational composition, affect the portfolio risk of financial institutions. They remove all banks from the sample that were subject to regulatory interventions, capital support measures, and distress mergers to obtain a clean identification of the impact of changes in board composition on bank risk taking in a sample of banks that does not contain seriously troubled institutions. They find that when board changes increase the representation of executives holding a $\mathrm{Ph} . \mathrm{D}$ degree the portfolio risk declines, suggesting that such executives apply better risk management techniques.

\subsection{Board diversity and performance}

The link between board diversity and shareholder value is relatively new, although there is literature since the 1990s that support expectations for improved performance and increased value for firms that implement diversity initiatives, thereby promoting action for managing diversity. ${ }^{119,120}$ Firms which encourage diversity can create competitive advantages in several dimensions of business performance: cost, attraction of human resources, marketing success, creativity and innovation, problem-solving quality and organisational flexibility. ${ }^{119}$ Also, wider diversity in board member characteristics has been advocated as a means of improving organisational performance by providing boards with new insights and 
perspectives. ${ }^{121}$ For Fields and Keys ${ }^{122(\mathrm{p} 13)}$ “ $a$ key factor in diversity's successful impact on firm performance is the value found in the heterogeneity of ideas, experiences, and innovations that diverse individuals bring to the firm."

The rationale behind the view of diversity as a positive force within boards builds on the assumption that the existence of multiple and divergent viewpoints within a board will decrease the likelihood that the agenda and initiatives will be dominated by the CEO and his/her inside director allies, thus improving the monitoring role of the board. ${ }^{123}$ Although board diversity has several dimensions the literature reveals a predominance of gender diversity.

Following the increased attention that gender diversity has received, boards around the world are under increasing pressure to choose female directors. In fact, many proposals for governance reform explicitly emphasise the importance of gender diversity on the board. The most prominent promotion of this kind of diversity took place in Norway, where since January 2008 all listed companies must abide by a $40 \%$ gender quota for female directors or face dissolution. ${ }^{124,125}$ Most of the national legislative initiatives are based on the view that the presence of women on boards creates value. Female board directors provide unique perspectives, experiences, and work styles as opposed to their male counterparts, ${ }^{126}$ which can greatly enhance deliberations of the board. These attributes will lead to better performance when combined with female characteristics such as communication and listening skills. ${ }^{127}$ Likewise, Bart and McQueen ${ }^{128}$ document that female directors can make significant contributions to the board due to their higher quality decision-making capability, which helps better explain the higher rates of return, more effective risk management and even lower rates of bankruptcy when women are present on the board. In addition, previous literature documents that female directors are in general better prepared than men for board meetings ${ }^{129}$ and have better attendance records. ${ }^{124}$ Moreover, Gul et $a l^{130}$ find that gender diversity improves stock price informativeness.

Although the positive benefits of female directorships have substantial empirical support, ${ }^{x x v i i}$ other studies fail to find a significant relationship between

\footnotetext{
${ }^{x x v i i}$ For instance, Carter et $a l^{131}$ find a significant positive association between the percentage of female directors and the performance of firms as measured by Tobin's Q in a sample of Fortune 1000 firms. Barta et al ${ }^{132}$ evidence that between 2008 and 2010, companies with more diverse top teams were also top financial performers. Also, Campbell and Mínguez-Vera ${ }^{133}$ in Spain and Hutchinson et al ${ }^{134}$ in Australia stress that gender diversity has a positive effect on performance.
} 
female directorships and the performance of the firm. ${ }^{18,135-137}$ The research by Adams and Ferreira ${ }^{124}$ shows that, although female directors are more effective than men in monitoring, the average effect of gender diversity on the performance of firms is negative.

In the light of the financial crisis, the link between performance and gender diversity has been raised and discussed publicly. Kristof ${ }^{138}$ noticed the lack of women in banks around the world and implicitly suggested that male domination may have contributed to their recent poor performance. Similarly, Harriet Harman, at the time, the UK Deputy Leader of the Labour Party, laid the blame for the financial meltdown on male domination of the top jobs at banks and-argued that the financial crisis would have been less extreme if Lehman Brothers had been "Lehman Sisters."139 In addition, the European Union commissioner, Michel Barnier suggested that having more women on the boards of banks would help prevent the kind of "group-think" that exacerbated the crisis. ${ }^{140, x x v i i i / x x i x}$ Accordingly, Muller-Kahle and Lewellyn, ${ }^{141}$ for a dataset of 74 US financial institutions over the period from 1997-2005, find that firms with gender diversity will be less likely to engage in subprime lending. Pathan and Faff $^{2}$ show that, although gender diversity improves US bank performance in the preSOX period, the positive effect of gender diminishes in both the post-SOX and the crisis periods. Using a sample of banks from different countries (Canada, France, Germany, Italy, the Netherlands, Spain, Sweden, the UK, and the US) during the period 2004-2010, García-Meca et $a l^{38}$ find that gender diversity improves bank performance, confirming the positive role of female directors on the performance of banks. On the contrary, Nguyen et $a l^{36}$ show that the gender of executives does not affect stock market returns of US banks and thus, according to them, gender does not matter. Regarding bank risk-taking, Berger et $a l^{118}$ find that board changes that increase the representation of female executives are not conducive to decreasing bank risk. Rather, a higher percentage of female board members significantly increases risk taking.

\footnotetext{
xxviii According to him, more diversity on boards of banks and other financial institutions, in particular more women, is not just one of better gender equality, but also one of better corporate governance.

xxix In November 2012, the European Commission proposed legislation that forces publicly listed companies in all, at the time, 27 member states, with the exception of small and medium enterprises, to reserve at least $40 \%$ of their non-executive director board seats for women by 2020 . However, this legislation aims to accelerate progress towards a better gender balance on the corporate boards and not, at least explicitly, corporate governance.
} 
National culture has an important impact on executive mindsets, as demonstrated by the fact that executives of different cultural background are not equally open to change in organisational strategy and leadership profiles ${ }^{142}$ and in the interpretation and response to strategic issues. ${ }^{143}$ Group members drawn from various nationalities tend to differ in ways that have substantial implications for group functioning, since national culture has a significant effect on the outlook, perceptions and behaviour of individuals. ${ }^{144}$

Masulis et $a l^{145}$ argue that firms with foreign independent directors (FID) exhibit significantly poorer performance, especially as their business presence in the FID's home region becomes less important. Also, FID display poor board meeting attendance records and are associated with a greater likelihood of intentional financial misreporting, higher CEO compensation, and a lower sensitivity of CEO turnover to performance.

Also, regarding banks, or even financial firms, there is a clear lack of empirical studies that examine the link between performance and nationality diversity, with the exceptions of the studies by Fernandes and Fich ${ }^{34}$ and García-Meca et al. ${ }^{38}$ Fernandes and Fich $^{34}$ find that the ratio of the number of different nationalities of directors to the board size, called nationality mix, has no impact on US bank stock returns during the crisis. In contrast, García-Meca et $a l^{38}$ document that nationality diversity, measured as the percentage of foreign directors, has a negative impact on bank performance, in nine countries. However, the percentage of foreign directors on the board may not be the best measure to represent nationality diversity, given that a high percentage can be obtained by merely having a large number of foreign directors of a single country.

Additionally, although no study analysing the relationship between age diversity and performance has been found, heterogeneity on age is neither significantly related to changes in corporate strategy ${ }^{146}$ nor facilitates innovativeness. ${ }^{147}$

\subsection{Board age and performance}

An individual's age is expected to influence strategic decision-making perspectives and choices. ${ }^{146}$ However, there are mixed views on how the average age of a director impacts agency conflicts and, consequently, the firm performance. ${ }^{30}$

On the one hand, older directors have more knowledge and experience, which might facilitate effective monitoring and attenuate agency costs. ${ }^{30}$ On the other hand, flexibility decreases and rigidity and resistance to change increase as people age. ${ }^{146}$ 
Also, older directors might lack the incentive and energy to actively monitor managers, thereby increasing agency problems. ${ }^{30}$

For Child ${ }^{148}$ younger men are able to expend more physical and mental effort on promoting the change and growth of their firms. In this viewpoint, young board members will be more vigorous and provide greater continuity into the future than will older board members. ${ }^{149}$ Also, lower managerial age is associated with both risktaking and strategic change, ${ }^{146,148}$ which seems to suggest that young managers are inclined to take risks at the expense of shareholders. On the other hand, younger managers are likely to have received their education more recently than older managers, so their technical knowledge should be superior ${ }^{147}$ and they have more favourable attitudes toward risk-taking. ${ }^{150}$ In this sense, younger aged boards are more likely to have the skills and cognitive resources needed to evaluate risk effectively as well as the willingness to take the risks that result in higher returns for shareholders.

Grove et $a l,{ }^{30}$ regarding US commercial banks, find that average director age exhibits a concave relationship with financial performance (measured by ROA of 2006 and 2007). Their results also reveal that the average director age has a negative and linear association with financial performance (measured by excess stock returns in 2006). Nguyen et $a l^{36}$ also argue that the age of the executive directors are performance relevant. But, contrary to Grove et $a l,{ }^{30}$ they show that the stock market returns are positively and significantly related to age. They contend that younger appointees have more incentive to raise their job security by engaging in risky and value-destroying activities. Therefore, market investors react less favorably to the appointment of a young appointee because they predict that this appointment will impose additional agency costs to the bank. In addition, Berger et $a l^{118}$ show that bank risk taking decreases as board age increases. This effect is statistically significant and also economically large.

\subsection{Board busyness and performance}

The literature disagrees on the link between the number of directorships held by board members and the performance of firms.

The first strand of literature argues that busy directors should positively affect the performance of the firm. Fama and Jensen ${ }^{8}$ suggest that multiple directorship signal director's abilities/quality. Similarly, Gilson, ${ }^{101}$ Kaplan and Reishus, ${ }^{151}$ Ferris et $a l^{152}$ and Fich and Shivdasani, ${ }^{153}$ amongst others, provide additional evidence that 
multiple directorships certify director quality. In this view, the number of directorships held by a director might proxy for reputational capital, with such individuals viewed as high quality directors, and higher quality directors are more frequently asked to serve on additional boards, Reputational Hypothesis. Thus "the directors who are considered "busy" are in fact chosen to be on so many boards precisely because of their high ability, which serves to offset the effect of their lack of time. "15(p88)

An alternative view is that directors who serve on many boards "will not be able to devote sufficient effort to any one board."15(p87) Thus, the second strand of literature defends that busy outside directors may be less effective monitors. The Busyness Hypothesis postulates that serving on too many directorships reduces directors' time and attention, and consequently their ability to monitor management, decreasing the value of the firm. Directors with multiple directorships are too busy to monitor and advise management. ${ }^{154}$ While the number of directorships, according to some studies, appears to be closely linked to the reputational capital of directors, other studies suggest that holding too many directorships may lower the effectiveness of outside directors as corporate monitors and decrease firm value (e.g., Loderer and Peyer, ${ }^{155}$ Fich and Shivdasani, ${ }^{156}$ Jackling and Johl, ${ }^{157}$ Cashman et al ${ }^{158}$ and Méndez et $a l^{159}$ ). Accordingly, Loderer and Peyer ${ }^{155}$ document that seat accumulation is negatively related to the value of the firm, possibly because of the conflicts of interest that directors are exposed to when they serve on several boards simultaneously and the insufficient time they can dedicate to any one of multiple mandates. Likewise, Jackling and Johl ${ }^{157}$ find evidence of a negative effect of busy outside directors on a firm's performance, suggesting that "busyness" did not add value in terms of networks and improvement of resource accessibility. Busy directors exhibit a higher tendency to be absent from board meetings ${ }^{160}$ and are detrimental to the monitoring capability of the board and its committees. ${ }^{159}$ In the financial crisis period, Francis et al ${ }^{18}$ find that the number of directorships has no impact on the performance of non-financial firms.

Regarding the relationship between board busyness and bank performance, Elyasiani and Zhang ${ }^{23}$ show that the performance of BHCs, for a sample of 116 BHCs from 2001 to 2010, is positively related to busyness of directors, supporting the idea that busy directors provide better advice due to their valuable knowledge and connections. Although busy directors are expected to bring more skills and 
connections as defended by Elyasiani and Zhang, ${ }^{23}$ the opaque and complex nature of the banking business requires more time and attention from a director in order to effectively fulfil the monitoring and advising roles. ${ }^{43}$ Muller-Kahle and Lewellyn ${ }^{141}$ report a positive relationship between outside director busyness and subprime lending, from 1997-2005, supporting the view that serving on multiple boards compromises a director's ability to effectively perform monitoring duties. This result is not consistent with the finding of Grove et $a l,{ }^{30}$ who find some (weak) evidence that busy directors impact on ROA but not on loan quality. In addition, Aebi et al, ${ }^{31}$ using as measure of busy board a dummy variable and Fernandes and Fich, ${ }^{34}$ using the average number of quoted boards positions (other directorships in publicly traded firms) held by board members, find that busy directors have no impact on bank performance during the financial crisis.

\subsection{Board activity and performance}

In the agency framework, the intensity of board activity, measured by the frequency of board meetings, may indicate an active monitoring role of corporate boards and so, influence corporate performance. Following this view, board meetings are beneficial to shareholders. Conger et $a l^{161}$ suggest that board meeting time is an important mechanism in improving the effectiveness of boards. The higher the frequency of meetings, the greater the supervision of top management, indicating a more effective monitoring role, which might mitigate agency costs and subsequently improve the performance of the firm. ${ }^{30}$ "The primary way in which directors obtain necessary information is by attending board meetings. "162(p227) An opposing view is that board meetings are not necessarily useful because, given their limited time, they cannot be used for the meaningful exchange of ideas among directors or with management. ${ }^{90}$ Moreover, routine tasks absorb much of the meetings, thereby limiting opportunities for outside directors to meaningfully exercise control over management. ${ }^{163}$ On the one hand, there are costs associated with board meetings, including managerial time, travel expenses and meeting fees of directors. On the other hand, there are benefits, including more time for directors to confer, define strategy and monitor management.

Andres and Vallelado ${ }^{1}$ find explanations both for and against a positive relation between the frequency of meetings and the performance of banks. Meetings provide board members with the opportunity to come together to discuss and exchange ideas 
on how they intend to monitor managers and bank strategy. Therefore, the more frequent the meetings, the closer the control over managers, the more significant the advisory role, factors that lead to a positive impact on performance (proactive boards). Furthermore, the complexity of the banking business and the importance of information require a more active and effective advisory role by boards. Additionally, boards of banks tend to be larger and have more committees, which are required to meet more frequently in order to be effective. ${ }^{12}$ However, frequent meetings might also be a result of the board's reaction to poor performance (reactive boards). ${ }^{1}$

Although bank directors are strongly urged to attend meetings by regulators, Adams and Ferreira, ${ }^{162}$ in a sample of 5707 directorships from 35 large US BCHs over the years 1986-1999, find that bank directors appear to have worse attendance records than their counterparts in non-financial firms. "Thus, regulatory pressure per se does not appear to be sufficient to induce directors to have good attendance records." 162(p229) Concerning US commercial banks, Grove et al ${ }^{30}$ show that board meeting frequency is positively associated with financial performance during the precrisis period (measured by excess stock return of 2006 and 2007) but not associated with loan quality. Also, for large US BHCs Adams and Mehran ${ }^{4}$ find that the natural logarithm of the number of board meetings has no impact on performance. In contrast, Liang et al, ${ }^{43}$ using a sample of 50 largest Chinese banks in the period of 2003-2010, find that the number of board meetings has a significantly positive effect on both performance and asset quality. The findings support the argument that frequent board meetings signal increased supervision of the top bank management in China. Board members might play a proactive role in the meetings to discuss and exchange ideas on how to supervise and advise managers, which could thereafter enhance bank performance. Aebi $e t a l^{31}$ specifically analyse the impact of the number of meetings of the risk committee on bank performance and they find a positive and significant effect. Thus, having a risk committee that meets more frequently positively influences the performance of banks during the 2007-2008 financial crisis. 


\section{Board characteristics and bank failures}

To the best of our knowledge, almost no research has empirically examined the direct relationship between corporate governance attributes and the failures of banks. "Empirically it has been difficult to establish a link between bank failures and corporate governance, partly because government rescues have masked the true extent of the banks' problems, and partly because so many other factors have contributed to bank failures. "3(p438)

Bank failures during the crisis have shown that the body of knowledge about bank defaults is apparently still not sufficient to prevent large number of banks from failing. ${ }^{164}$ Most research of bank defaults has focused on the impact of accounting variables, such as capital ratios (e.g. Martin, ${ }^{165}$ Pettway and Sinkey, ${ }^{166}$ Lane et al, ${ }^{167}$ Espahbodi, ${ }^{168}$ Cole and Gunther, ${ }^{169,}{ }^{170}$ Helwege, ${ }^{171}$ Kolari et al, ${ }^{172}$ Schaeck ${ }^{173}$ and Cole and White $\left.{ }^{174}\right)$. Berger and Bouwman, ${ }^{175}$ for example, examine how capital affects a bank's performance (survival and market share) during both financial crises (including the recent crisis) and normal times. They conclude that having more capital increases the probability of survival of small banks at all times and of medium and large banks during banking crises.

Given the scarcity of research on the influence of corporate governance mechanisms on bank defaults, we chose in this sub-section, contrary to the previous one, to make a joint analysis of the impact of board characteristics on financial failures of banks and not to make an analysis of the influence of these characteristics one at a time.

Hambrick and D'Aveni ${ }^{176(\mathrm{p} 1)}$ characterise bankruptcy as a "protracted process of decline" and a "downward spiral". Therefore, substantial financial distress effects are incurred well prior to default. ${ }^{177}$ "According to the OCC [Office of the Comptroller do the Currency], the ultimate causes of bank failures are an uninformed or inattentive board of directors and/or management, overly aggressive activity by the board and/or management, problems involving the chief executive officer, and other problems related to board oversight and management deficiencies. "178(p282)

The financial distress of banks in the wake of the recent financial crisis has triggered a discussion about the role of corporate governance structures in the stability of financial institutions. Nevertheless, the finding that corporate governance impacts on bank stability, emphasising bank risk-taking behaviour, was already found long before the recent financial crisis. 
Regarding financial distress, for Simpson and Gleason, ${ }^{178}$ using a sample of 287 banking firms for the period 1989-1993, board size and the percentage of insiders on the board do not impact on the future probability of financial distress, contrary to the CEO duality that has a significant effect. Specifically, CEO duality decreases the probability of financial distress five years later.

Concerning board characteristics and their influence on bank failures, Berger et $a l,{ }^{164}$ for a sample of US commercial banks during the period of 2007-2010, report that the number of outside directors, the number of chief officers, the number of other corporate insiders and the board size do not have influence on a bank's default probability, while the CEO duality has a negative impact one year and two years prior to default. Thus, they conclude that the management structure of a given bank is not decisive for its overall stability. 


\section{Conclusions}

Banks remarkably differ from non-financial firms. Due to their particularities and their impact on the stability of the financial system and the overall economy, failures in bank governance are more critical than failures in unregulated nonfinancial firms governance. Thus, we examined how bank governance differs from governance in the other type of firms and how governance in banks is conditioned by their special attributes.

During the financial crisis the governance mechanisms gained significantly more importance especially concerning the effectiveness of the board of banks, being a topic of intense policy discussion. A bank's board plays a crucial role in achieving effective governance. Specifically, it is a key mechanism to supervise managers' behaviour and decisions and to advise them on strategy setting and implementation, providing critical resources to the firm (e.g., such as knowledge, networks and connections). The role of the board of directors takes on special importance in a framework of greater opacity and complexity, intense regulation and higher asymmetric information, that characterise banking activity.

Many academic, economists and policy documents have outlined recommendations about banks governance namely about the independence of the board of directors. The underlying idea is that numerous characteristics of the board impact on directors' incentives and ability to effectively carry out their duties and, consequently, have an impact on performance (and risk-taking). In addition, the effect of board characteristics on bank value depends on the trade-off between the advantages and disadvantages of monitoring and advising.

In this paper, we review the vast body of literature devoted to the relationship between bank board characteristics and bank performance, in the U.S. setting and in international settings (although most studies use data from US, which is more abundant) in the crisis and non-crisis periods. The survey suggests that some of the empirical findings commonly found in non-financial institutions (e.g. board independence and board size) do not hold for banking firms. Several studies show that board independence is not positively associated with bank performance. Independent directors are not (necessarily) beneficial for banks as they not always have the adequate knowledge about the specificities and complexity of the banking business. Thus, the costs related to less satisfactory advice seem to outweigh the monitoring advantages of independent directors. Similarly, the positive link between board size 
and bank performance is not found in several studies. Although larger boards are advantageous because they increase the pool of expertise and resources available to banks, boards with too many members can lead to problems of coordination, control and flexibility in the decision-making process. Additionally, for instance, board experience is important for bank performance and positively related to it, as evidenced by the existing research. Also, the literature stresses that a widespread lack of financial expertise on the boards of a large number of banks appears to have played a significant role in the recent crisis.

Finally, we note that the literature on the relationship between board features and bank failures is virtually non-existent. Therefore, future work needs to examine with much more detail the impact of the corporate governance mechanisms in general and board characteristics in particular on bank defaults. The need to acquire knowledge about bank failures was particularly clear during the global financial crisis (e.g., the imminent default of many banks worldwide forced governments to massive and costly interventions in order to ensure their survival). 


\section{References}

1. Andres, P. and Vallelado, E. (2008) Corporate governance in banking: The role of the board of directors. Journal of Banking \& Finance 32(12): 2570-80.

2. Pathan, S. and Faff, R. (2013) Does board structure in banks really affect their performance? Journal of Banking \& Finance 37(5): 1573-89.

3. Becht, M., Bolton, P. and Röell, A. (2011) Why bank governance is different. Oxford Review of Economic Policy 27(3): 437-63.

4. Adams, R. B. and Mehran, H. (2012) Bank board structure and performance: Evidence for large bank holding companies. Journal of Financial Intermediation 21(2): 243-67.

5. Hopt, K. J. (2013) Corporate governance of banks and other financial institutions after the financial crisis. Journal of Corporate Law Studies. 13(2): 219-53.

6. BCBS, Basel Committee on Banking Supervision, (2015) Corporate governance principles for banks, July, http://www.bis.org/bcbs/publ/d328.htm, accessed 6 July 2016.

7. Coles, J. L., Daniel, N. D. and Naveen, L. (2008) Boards: Does one size fit all? Journal of Financial Economics 87(2): 329-56.

8. Fama, E. F. and Jensen, M. C. (1983) Separation of ownership and control. The Journal of Law and Economics 26(2): 301-25.

9. Williamson, O. E. (1983) Organization form, residual claimants, and corporate control. The Journal of Law and Economics 26(2): 351-66.

10. Weisbach, M. S. (1988) Outside directors and CEO turnover. Journal of Financial Economics 20: 431-60.

11. John, K. and Senbet, L. W. (1998) Corporate governance and board effectiveness. Journal of Banking \& Finance 22(4): 371-403.

12. Adams R. and Mehran, H. (2003) Is corporate governance different for bank holding companies? Federal Reserve Bank of New York Economic Policy Review 9(1): 123-42.

13. Raheja, C. G. (2005) Determinants of board size and composition: A theory of corporate boards. Journal of Financial and Quantitative Analysis 40(2): 283-306.

14. Adams, R. B. and Ferreira, D. (2007) A theory of friendly boards. The Journal of Finance 62(1): 217-50.

15. Adams, R. B., Hermalin, B. E. and Weisbach, M. S. (2010) The role of boards of directors in corporate governance: A conceptual framework and survey. Journal of Economic Literature 48(1): 58-107.

16. Schwartz-Ziv, M. and Weisbach, M. S. (2013) What do boards really do? Evidence from minutes of board meetings. Journal of Financial Economics. 108(2): 349-66.

17. Kirkpatrick, G. (2009) Corporate governance lessons from the financial crisis. OECD Journal: Financial Market Trends 2009/1(1): 61-87.

18. Francis, B. B., Hasan, I. and Wu, Q. (2012) Do corporate boards matter during the current financial crisis? Review of Financial Economics 21(2): 39-52.

19. BCBS, Basel Committee on Banking Supervision, (2010) Principles for enhancing corporate governance Final document, October, http://www.bis.org/publ/bcbs176.htm, accessed 10 July 2016.

20. Hermalin, B. E. and Weisback, M. S. (2003) Board of directors as an endogenously determined institution: A survey of the economic literature. Federal Reserve Bank of New York Economic Policy Review 9(1): 7-26. 
21. Roberts, M. R. and Whited, T. M. (2012) Endogeneity in empirical corporate finance. Simon School Working Paper No. FR 11-29, http://ssrn.com/abstract=1748604 or http://dx.doi.org/10.2139/ssrn.1748604

22. Wintoki, M.B., Linck, J. S and Netter, J. M. (2012) Endogeneity and the dynamics of internal corporate governance. Journal of Financial Economics 105(3): 581-606.

23. Elyasiani, E and Zhang, L. (2015) Bank holding company performance, risk, and "busy" board of directors. Journal of Banking \& Finance 60: 239-51.

24. Adams, R. B. (2012) Governance and the financial crisis. International Review of Finance 12(1): 7-38.

25. Erkens, D. H., Hung, M. and Matos, P. (2012) Corporate governance in the 2007-2008 financial crisis: Evidence from financial institutions worldwide. Journal of Corporate Finance 18(2): 389-411.

26. Shleifer, A. and Vishny, R. W. (1997) A survey of corporate governance. The Journal of Finance 52(2): 737-83.

27. de Haan, J. and Vlahu, R. (2015) Corporate governance of banks: A survey. Journal of Economic Surveys 30(2): 228-277.

28. Barro, J.R. and Barro, R. J. (1990) pay, performance, and turnover of bank CEOs. Journal of Labor Economics 8(4): 448-81.

29. Fahlenbrach, R. and Stulz, R. M. (2011) Bank CEO incentives and the credit crisis. Journal of Financial Economics 99(1): 11-26.

30. Grove, H., Patelli, L., Victoravich, L. M. and Xu, P. (2011) Corporate governance and performance in the wake of the financial crisis: Evidence from US commercial banks. Corporate Governance: An International Review 19(5): 418-36.

31. Aebi, V., Sabato, G. and Schmid, M. (2012) Risk management, corporate governance, and bank performance in the financial crisis. Journal of Banking \& Finance 36(12): 3213-26.

32. Beltratti, A. and Stulz, R. M. (2012) The credit crisis around the globe: Why did some banks perform better? Journal of Financial Economics 105(1): 1-17.

33. Fahlenbrach, R., Prilmeier, R. and Stulz, R. M. (2012) This time is the same: Using bank performance in 1998 to explain bank performance during the recent financial crisis. The Journal of Finance 67(6): 2139-85.

34. Fernandes, N. and Fich, E. M. (2013) Does financial experience help banks during credit crises?, $\underline{\text { http://ssrn.com/abstract=1409557 or http://dx.doi.org/10.2139/ssrn.1409557 }}$

35. Minton, B. A., Taillard, J. P. and Williamson, R. (2014) Financial expertise of the board, risk taking, and performance: evidence from bank holding companies. Journal of Financial \& Quantitative Analysis 49(2): 351-80.

36. Nguyen, D. D., Hagendorff, J. and Eshraghi, A. (2015) Which executive characteristics create value in banking? Evidence from appointment announcements. Corporate Governance: An International Review 23(2): 112-28.

37. Staikouras, P. K., Staikouras, C. K. and Agoraki, M.-E. K. (2007) The effect of board size and composition on European bank performance. European Journal of Law and Economics 23(1): 1-27.

38. García-Meca, E., García-Sánchez, I.-M. and Martínez-Ferrero, J. (2015) Board diversity and its effects on bank performance: An international analysis. Journal of Banking \& Finance 53(1): 202-14. 
39. Berger, A. N., Clarke, G. R. G., Cull, R., Klapper, L. and Udell, G. F. (2005) Corporate governance and bank performance: A joint analysis of the static, selection, and dynamic effects of domestic, foreign, and state ownership. Journal of Banking \& Finance 29(8-9): 2179-221.

40. Lin, X. and Zhang, Y. (2009) Bank ownership reform and bank performance in China. Journal of Banking \& Finance 33(1): 20-9.

41. Rowe, W., Shi, W. and Wang, C. (2011) Board governance and performance of Chinese banks. Banks and Bank Systems 6(1): 26-40.

42. Westman, H. (2011) The impact of management and board ownership on profitability in banks with different strategies. Journal of Banking \& Finance 35(12): 3300-18.

43. Liang, Q., Xu, P. and Jiraporn, P. ( 2013) Board characteristics and Chinese bank performance. Journal of Banking \& Finance 37(8): 2953-68.

44. Pi, L. and Timme, S. G. (1993) Corporate control and bank efficiency. Journal of Banking \& Finance 17(2): 515-30.

45. Hau, H. and Thum, M. (2009) Subprime crisis and board (in-)competence: Private versus public banks in Germany. Economic Policy 24(60): 701-52.

46. Wang, W.-K., Lu, W.-M. and Lin, Y.-L. (2012) Does corporate governance play an important role in BHC performance? Evidence from the U.S. Economic Modelling 29(3): 751-60.

47. Cuñat, V. and Garicano, L. (2010) Did good cajas extend bad loans? Governance, human capital and loan portfolios. MPRA Paper No. 42434, https://mpra.ub.uni-muenchen.de/42434/

48. Carty, R. and Weiss, G. (2012) Does CEO duality affect corporate performance? Evidence from the US banking crisis. Journal of Financial Regulation and Compliance 20(1): 26-40.

49. Boyd, J. H. and Runkle, D. E. (1993) Size and performance of banking firms. Journal of Monetary Economics 31(1): 47-67.

50. Stern, G. H. and Feldman, R. J. (2004) Too Big to Fail: The Hazards of Bank Bailouts. Washington, DC: Brookings Institution Press.

51. Mishkin, F. S., Stern, G. and Ron F. (2006) How big a problem is too big to fail? A review of Gary Stern and Ron Feldman's too big to fail: The hazards of bank bailouts. Journal of Economic Literature 44(4): 988-1004.

52. Denis, D. K. and McConnell, J. J. (2003) International corporate governance. Journal of Financial and Quantitative Analysis 38(1): 1-36.

53. Tirole, J. (2001) Corporate Governance. Econometrica 69(1): 1-35.

54. Goergen, M. (2007) What do we know about different systems of corporate governance? Journal of Corporate Law Studies 7(1): 1-15.

55. OECD (2004) OECD Principles of corporate governance, http://www.oecd.org/corporate/ca/corporategovernanceprinciples/31557724.pdf, accessed 15 July 2016.

56. Pathan, S. (2009) Strong boards, CEO power and bank risk-taking. Journal of Banking \& Finance 33(7): 1340-50.

57. Macey, J. R. and O'Hara, M. (2003) The corporate governance of banks. Federal Reserve Bank of New York Economic Policy Review 9(1): 91-107. 
58. Fernandes, C., Farinha, J., Martins, F. V. and Mateus, C. (2016) Determinants of European banks' bailouts following the 2007-2008 financial crisis. Journal of International Economic Law 19(3): 707-42.

59. Breitenfellner, B. and Wagner, N. (2010) Government intervention in response to the subprime financial crisis: The good into the pot, the bad into the crop. International Review of Financial Analysis 19(4): 289-97.

60. Grossman, E. and Woll, C. (2014) Saving the banks: The political economy of bailouts. Comparative Political Studies 47(4): 574-600.

61. Mülbert, P. O. (2009) Corporate governance of banks. European Business Organization Law Review (EBOR) 10(3): 411-36.

62. Adams, R. B. (2010) Governance of banking institutions. In: Baker HK, Anderson R (eds.) Corporate Governance: A Synthesis of Theory, Research, and Practice. Robert W. Kolb Series in Finance. Hoboken, N.J.: John Wiley \& Sons, Inc, pp. 451-67.

63. Saghi-Zedek, N. and Tarazi, A. (2015) Excess control rights, financial crisis and bank profitability and risk. Journal of Banking \& Finance 55: 361-79.

64. United States Financial Crisis Inquiry Commission (2011), The financial crisis inquiry report: Final report of the national commission on the causes of the financial and economic crisis in the United States, January, https://www.gpo.gov/fdsys/pkg/GPO-FCIC/pdf/GPO-FCIC.pdf, accessed 21 July 2016.

65. Walker, D. (2009) A review of corporate governance in UK banks and other financial industry entities Final recommendations", November, http://www.ecgi.org/codes/code.php?code_id=270, accessed 25 July 2016.

66. Caprio, G. and Levine, R. (2002) Corporate governance of banks: Concepts and international observations. Paper presented at the Global Corporate Governance Forum Research Network Meeting; 5 April.

67. Levine, R. (2004) The corporate governance of banks: A concise discussion of concepts and evidence. World Bank Policy Research Working Paper No. 3404, https://ssrn.com/abstract=625281

68. Laeven, L. (2013) Corporate governance: What's special about banks? Annual Review of Financial Economics 5: 63-92.

69. Prowse, S. (1997) Corporate control in commercial banks. The Journal of Financial Research 20(4): 509-27.

70. Morgan, D. P. (2002) Rating banks: Risk and uncertainty in an opaque industry. The American Economic Review 92(4): 874-88.

71. Devriese, J., Dewatripont M., Heremans, D. and Nguyen, G. (2004) Corporate governance, regulation and supervision of banks. Financial Stability Review 2(1): 95-120.

72. Van der Elst, C. (2015) Corporate Governance and Banks: How Justified is the Match? European Corporate Governance Institute (ECGI) - Law Working Paper No. 284/2015, https://ssrn.com/abstract=2562072 or http://dx.doi.org/10.2139/ssrn.2562072

73. John, K., De Masi, S. and Paci, A. (2016) Corporate governance in banks. Corporate Governance: An International Review 24(1): 303-21.

74. Laeven, L. (2002) Bank risk and deposit insurance. World Bank Economic Review 16(1): 109-37.

75. Dell'Ariccia, G., Laeven, L. and Igan, D. (2012) Credit booms and lending standards: Evidence from the subprime mortgage market. Journal of Money, Credit and Banking 44(2-4): 367-84.

76. Carlin, B. I., Kogan, S. and Lowery, R. (2013) Trading complex assets. The Journal of Finance. 68(5): 193760. 
77. Rötheli, T. F. (2010) Causes of the financial crisis: Risk misperception, policy mistakes, and banks' bounded rationality. The Journal of Socio-Economics 39(2): 119-26.

78. Buiter, W. H. (2007) Lessons from the 2007 financial crisis. CEPR Discussion Paper No. DP6596, https://ssrn.com/abstract=1140525

79. Furfine, C. H. (2001) Banks as monitors of other banks: Evidence from the overnight federal funds market. Journal of Business 74(1): 33-57.

80. John, K. and Qian, Y. (2003) Incentive features in CEO compensation in the banking industry. Federal Reserve Bank of New York Economic Policy Review 9(1): 109-21.

81. DeAngelo, H. and Stulz, R. M. (2015) Liquid-claim production, risk management, and bank capital structure: Why high leverage is optimal for banks. Journal of Financial Economics 116(2): 219-36.

82. Srivastav, A. and Hagendorff, J. (2016) Corporate Governance and Bank Risk-taking. Corporate Governance: An International Review 24(3): 334-45.

83. Laeven, L. and Levine, R. (2009) Bank governance, regulation and risk taking. Journal of Financial Economics 93(2): 259-75.

84. John, K., Mehran, H. and Qian, Y. (2010) Outside monitoring and CEO compensation in the banking industry. Journal of Corporate Finance 16(4): 383-99.

85. Ellul, A. and Yerramilli, V. (2013) Stronger risk controls, lower risk: Evidence from U.S. bank holding companies. The Journal of Finance 68(5): 1757-803.

86. Diamond, D. W. (1984) Financial intermediation and delegated monitoring. The Review of Economic Studies 51(3): 393-414.

87. Ciancanelli, P. and Reyes-Gonzalez, J. A. (2000) Corporate governance in banking: A conceptual framework, https://ssrn.com/abstract=253714 or http://dx.doi.org/10.2139/ssrn.253714

88. Scharfstein, D. (1988) The disciplinary role of takeovers. The Review of Economic Studies 55(2): 185-99.

89. Jensen, M. C. (1988) Takeovers: Their causes and consequences. Journal of Economic Perspectives 2(1): 21-48.

90. Jensen, M. C. (1993) The modern industrial revolution, exit, and the failure of internal control systems. The Journal of Finance 48(3): 831-80.

91. Boot A. W. A. and Thakor, A. V. (1993) Self-interested bank regulation. The American Economic Review 83(2): 206-12.

92. Mizruchi, M. S. (1983) Who controls whom? An examination of the relation between management and boards of directors in large american corporations. Academy of Management Review 8(3): 426-35.

93. Baysinger, B. D. and Butler, H. N. (1985) Corporate governance and the board of directors: Performance effects of changes in board composition. Journal of Law, Economics, and Organization 1(1): 101-24.

94. Helland, E. and Sykuta, M. (2004) Regulation and the evolution of corporate boards: monitoring, advising, or window dressing? The Journal of Law and Economics 47(1): 167-93.

95. Robinson, D., Robinson, M. and Sisneros, C. (2012) Bankruptcy outcomes: Does the board matter? Advances in Accounting 28(2): 270-8.

96. Hermalin, B. E. and Weisbach, M. S. (1998) Endogenously chosen boards of directors and their monitoring of the CEO. The American Economic Review 88(1): 96-118.

97. Almazan, A. and Suarez, J. (2003) Entrenchment and severance pay in optimal governance structures. The Journal of Finance 58(2): 519-48. 
98. Coles, J. L., Lemmon, M. L. and Meschke, J. F. (2012) Structural models and endogeneity in corporate finance: The link between managerial ownership and corporate performance. Journal of Financial Economics 103(1): 149-68.

99. Harris, M. and Raviv, A. (2008) A theory of board control and size. The Review of Financial Studies 21(4): 1797-832.

100. Kim, K., Mauldin, E. and Patro, S. (2014) Outside directors and board advising and monitoring performance. Journal of Accounting and Economics 57(2-3): 110-31.

101. Gilson, S. C. (1990) Bankruptcy, boards, banks, and blockholders: Evidence on changes in corporate ownership and control when firms default. Journal of Financial Economics 27(2): 355-87.

102. Hermalin, B. E. and Weisbach, M. S. (1988) The determinants of board composition. The RAND Journal of Economics 19(4): 589-606.

103. Quint, M. (1993) Bank directors face rising risks. The New York Times, 26 March.

104. Pathan, S, and Skully, M. (2010) Endogenously structured boards of directors in banks. Journal of Banking \& Finance 34(7): 1590-606.

105. Kroszner, R. S. and Strahan, P. E. (2001) Throwing good money after bad? Board connections and conflicts in bank lending. NBER Working Paper Series No. 8694, http://www.nber.org/papers/w8694

106. Booth, J. R., Cornett, M. M. and Tehranian, H. (2002) Boards of directors, ownership, and regulation. Journal of Banking and Finance 26: 1973-96.

107. Lipton, M. and Lorsch, J. W. (1992) A modest proposal for improved corporate governance. The Business Lawyer 48(1): 59-77.

108. Berger, P. G., Ofek, E. and Yermack, D. L. (1997) Managerial entrenchment and capital structure decisions. The Journal of Finance 52(4): 1411-38.

109. Mallette, P. and Fowler, K. L. (1992) Effects of board composition and stock ownership on the adoption of "poison pills". Academy of Management Journal 35(5): 1010-35.

110. Brickley, J. A., Coles, J. L. and Jarrell, G. (1997) Leadership structure: Separating the CEO and Chairman of the board. Journal of Corporate Finance 3(3): 189-220.

111. Dey, A., Engel, E. and Liu, X. (2011) CEO and board chair roles: To split or not to split? Journal of Corporate Finance 17(5): 1595-618.

112. Pfeffer, J. (1972) Size and composition of corporate boards of directors: The organization and its environment. Administrative Science Quarterly 17(2): 218-28.

113. Boyd, B. (1990) Corporate linkages and organizational environment: A test of the resource dependence model. Strategic Management Journal 11(6): 419-30.

114. von Meyerinck, F., Oeschb, D. and Schmid, M. (2013) Is director industry experience valuable?, http://ssrn.com/abstract=2051063 or http://dx.doi.org/10.2139/ssrn.2051063

115. Guerrera, F. and Larsen, P. T. Gone by the board? Why bank directors did not spot credit risks. Financial Times, 25 June.

116. Mehran, H., Morrison, A. and Shapiro, J. (2011) Corporate governance and banks: What have we learned from the financial crisis? FRB of New York Staff Report No. 502, http://ssrn.com/abstract=1880009

117. SEC, Securities and Exchange Commission, (2009) Proxy disclosure enhancements, December, http://www.sec.gov/rules/final/2009/33-9089-secg.htm, accessed 30 July 2016. 
118. Berger, A. N., Kick, T. and Schaeck, K. (2014) Executive board composition and bank risk taking. Journal of Corporate Finance 28: 48-65.

119. Cox, T. H. and Blake, S. (1991) Managing cultural diversity: Implications for organizational competitiveness. Academy of Management Executive 5(3): 45-56.

120. Robinson, G. and Dechant, K. (1997) Building a business case for diversity. Academy of Management Executive 11(3): 21-31.

121. Siliciano, J. I. (1996) The relationship of board member diversity to organizational performance. Journal of Business Ethics 15(12): 1313-20.

122. Fields, M. A. and Keys, P. Y. The emergence of corporate governance from Wall St. to Main St.: outside directors, board diversity, earnings management, and managerial incentives to bear risk. The Financial Review. 2003;38(1):1-24.

123. Kim, I., Pantzalis, C. and Park, J. C. (2013) Corporate boards' political ideology diversity and firm performance. Journal of Empirical Finance 21(1): 223-40.

124. Adams, R. B. and Ferreira, D. (2009) Women in the boardroom and their impact on governance and performance. Journal of Financial Economics 94(2): 291-309.

125. Adams, R. B. and Funk, P. (2012) Beyond the glass ceiling: Does gender matter? Management Science 58(2): 219-35.

126. Daily, C. M. and Dalton, D. R. (2003) Women in the boardroom: A business imperative. Journal of Business Strategy 24(5): 8-9.

127. Julizaerma, M. K. and Sori, Z. M . (2012) Gender diversity in the boardroom and firm performance of Malaysian public listed companies. Procedia - Social and Behavioral Sciences 65(1): 1077-85.

128. Bart, C. and McQueen, G. (2013) Why women make better directors. International Journal of Business Governance and Ethics 8(1): 93-9.

129. Huse, M. and Solberg, A. G. (2006) Gender-related boardroom dynamics: How Scandinavian women make and can make contributions on corporate boards. Women In Management Review. 21(1): 113-30.

130. Gul, F. A., Srinidhi, B. and Ng, A. C. (2011) Does board gender diversity improve the informativeness of stock prices? Journal of Accounting and Economics 51(3): 314-38.

131. Carter, D. A., Simkins, B. J. and Simpson, W. G. (2003) Corporate governance, board diversity, and firm value. The Financial Review 38(1): 33-53.

132. Barta, T., Kleiner, M. and Neumann, T. (2012) Is there a payoff from top-team diversity? McKinsey Quarterly. 2: 13-15.

133. Campbell, K. and Mínguez-Vera, A. (2008) Gender diversity in the boardroom and firm financial performance. Journal of Business Ethics 83(3): 435-51.

134. Hutchinson, M., Mack, J. and Plastow, K. (2015) Who selects the 'right' directors? An examination of the association between board selection, gender diversity and outcomes. Accounting \& Finance 55(4): 1071-103.

135. Shrader, C. B., Blackburn, V. B. and Iles, P. (1997) Women in management and firm financial performance: An exploratory study. Journal of Managerial Issues 9(3): 355-72.

136. Farrell, K. A. and Hersch, P. L. (2005) Additions to corporate boards: The effect of gender. Journal of Corporate Finance 11(1-2): 85-106.

137. Rose, C. (2007) Does female board representation influence firm performance? The Danish evidence. Corporate Governance: An International Review 15(2): 404-13. 
138. Kristof, N. D. (2009) Mistresses of the universe. The New York Times, 7 February.

139. Morris, N. (2009) Harriet Harman: 'If only it had been Lehman Sisters'. The Independent, 4 August.

140. Treanor, J. (2011) EU calls for women to make up one-third of bank directors. The Guardian, 21 June.

141. Muller-Kahle, M. I. and Lewellyn, K. B. (2011) Did board configuration matter? The case of US subprime lenders. Corporate Governance: An International Review 19(5): 405-17.

142. Geletkanycz, M. A. (1997) The salience of 'culture's consequences': The effects of cultural values on top executive commitment to the status quo. Strategic Management Journal 18(8): 615-34.

143. Schneider, S. C. and De Meyer, A. (1991) Interpreting and responding to strategic issues: The impact of national culture. Strategic Management Journal 12(4): 307-20.

144. Hambrick, D. C., Davidson, S. C., Snell S. A. and Snow, C. C. (1998) When groups consist of multiple nationalities: Towards a new understanding of the implications. Organization Studies 19(2): 181-205.

145. Masulis, R. W., Wang, C. and Xie, F. (2012) Globalizing the boardroom-The effects of foreign directors on corporate governance and firm performance. Journal of Accounting and Economics 53(3): 527-54.

146. Wiersema, M. F. and Bantel, K. A. (1992) Top management team demography and corporate strategic change. Academy of Management Journal 35(1): 91-121.

147. Bantel, K. A. and Jackson, S. E. (1989) Top management and innovations in banking: Does the composition of the top team make a difference? Strategic Management Journal 10: 107-24.

148. Child, J. (1974) Managerial and organizational factors associated with company performance - Part I. Journal of Management Studies 11(3): 175-89.

149. Cochran, P. L., Wartick, S. L. and Wood, R. A. (1984) The average age of boards and financial performance, revisited. Quarterly Journal of Business and Economics 23(4): 57-63.

150. Vroom, V. H. and Pahl, B. (1971) Relationship between age and risk taking among managers. Journal of Applied Psychology 55(5): 399-405.

151. Kaplan, S. N. and Reishus, D. (1990) Outside directorships and corporate performance. Journal of Financial Economics 27(2): 389-410.

152. Ferris, S. P., Jagannathan, M. and Pritchard, A. C. (2003) Too busy to mind the business? Monitoring by directors with multiple board appointments. The Journal of Finance 58(3): 1087-112.

153. Fich, E. M. and Shivdasani, A. (2007) Financial fraud, director reputation, and shareholder wealth. Journal of Financial Economics 86(2): 306-36.

154. Benson, B. W., Davidson III, W. N., Davidson, T. R. and Wang, H. (2015) Do busy directors and CEOs shirk their responsibilities? Evidence from mergers and acquisitions. The Quarterly Review of Economics and Finance 55: 1-19.

155. Loderer, C. and Peyer, U. (2002) Board overlap, seat accumulation and share prices. European Financial Management 8(2): 165-92.

156. Fich, E. M. and Shivdasani, A. (2006) Are busy boards effective monitors? The Journal of Finance 61(2): 689-724.

157. Jackling, B. and Johl, S. (2009) Board structure and firm performance: Evidence from India's top companies. Corporate Governance: An International Review 17(4):492-509. 
158. Cashman, G. D., Gillan, S. L. and Jun, C. (2012) Going overboard? On busy directors and firm value. Journal of Banking \& Finance 36(12): 3248-59.

159. Méndez, C. F., Pathan, S. and García, A. R. (2015) Monitoring capabilities of busy and overlap directors: Evidence from Australia. Pacific-Basin Finance Journal 35: 444-69.

160. Jiraporn, P., Davidson III $\{$ Cole, 1995 \#1193\}, W. N., DaDalt, P. and Ning, Y. (2009) Too busy to show up? An analysis of directors' absences. The Quarterly Review of Economics and Finance 49(3): 115971.

161. Conger, J. A., Finegold, D. and Lawler, E. E. (1998) Appraising boardroom performance. Harvard Business Review 76(1): 136-48.

162. Adams, R. B. and Ferreira, D. (2012) Regulatory pressure and bank directors' incentives to attend board meetings. International Review of Finance 12(2): 227-48.

163. Vafeas, N. (1999) Board meeting frequency and firm performance. Journal of Financial Economics 53(1): $113-42$.

164. Berger, A. N., Imbierowicz, B. and Rauch, C. (2012) The roles of corporate governance in bank failures during the recent financial crisis. European Banking Center Discussion Paper No. 2012-023, http://ssrn.com/abstract $=2163546$

165. Martin, D. (1977) Early warning of bank failure. A logit regression approach. Journal of Banking and Finance 1(3): 249-76.

166. Pettway, R. H. and Sinkey, J. F. (1980) Establishing on-site bank examination priorities: An early-warning system using accounting and market information. The Journal of Finance 35(1): 137-50.

167. Lane, W. R., Looney, S. W. and Wansley, J. W. (1986) An application of the cox proportional hazards model to bank failure. Journal of Banking \& Finance 10(4): 511-31.

168. Espahbodi, P. (1991) Identification of problem banks and binary choice models. Journal of Banking \& Finance 15(1): 53-71.

169. Cole, R. A. and Gunther, J. W. (1995) Separating the likelihood and timing of bank failure. Journal of Banking and Finance 19(6): 1073-89.

170. Cole, R. A. and Gunther, J. W. (1998) Predicting bank failures: A comparison of on- and off-site monitoring systems. Journal of Financial Services Research 13(2): 103-17.

171. Helwege, J. (1996) Determinants of savings and loan failures: Estimates of a time-varying proportional hazard function. Journal of Financial Services Research 10(4): 373-92.

172. Kolari, J., Glennon, D., Shin, H. and Caputo, M. (2002) Predicting large US commercial bank failures. Journal of Economics and Business 54(4): 361-87.

173. Schaeck, K. (2008) Bank liability structure, FDIC loss, and time to failure: A quantile regression approach. Journal of Financial Services Research 33(3): 163-79.

174. Cole, R. A. and White, L. J. (2012) Déjà vu all over again: The causes of U.S. commercial bank failures this time around. Journal of Financial Services Research 42(1-2): 5-29.

175. Berger, A. N. and Bouwman, C. H. S. (2013) How does capital affect bank performance during financial crises? Journal of Financial Economics 109(1): 146-76.

176. Hambrick, D. C. and D'Aveni, R. A. (1988) Large corporate failures as downward spirals. Administrative Science Quarterly 33(1): 1-23. 
177. Elloumi, F. and Gueyié, J. P. (2001) Financial distress and corporate governance: an empirical analysis. Corporate Governance: The International Journal of Business in Society 1(1): 15-23.

178. Simpson, W. G. and Gleason, A. E. (1999) Board structure, ownership, and financial distress in banking firms. International Review of Economics and Finance 8(3): 281-92. 